\title{
Neuroendocrine neoplasms: current and potential diagnostic, predictive and prognostic markers
}

\author{
Aura D Herrera-Martínez¹,2, Leo J Hofland1, María A Gálvez Moreno², Justo P Castaño², Wouter W de Herder¹ and \\ Richard A Feelders ${ }^{1}$
}

'Division of Endocrinology, Department of Internal Medicine, Erasmus MC, University Medical Center Rotterdam, Rotterdam, the Netherlands

2Maimonides Institute for Biomedical Research of Cordoba (IMIBIC); Reina Sofia University Hospital, Córdoba, Spain

Correspondence should be addressed to R A Feelders: r.feelders@erasmusmc.nl

\begin{abstract}
Some biomarkers for functioning and non-functioning neuroendocrine neoplasms (NENs) are currently available. Despite their application in clinical practice, results should be interpreted cautiously. Considering the variable sensitivity and specificity of these parameters, there is an unmet need for novel biomarkers to improve diagnosis and predict patient outcome. Nowadays, several new biomarkers are being evaluated and may become future tools for the management of NENs. These biomarkers include (1) peptides and growth factors; (2) DNA and RNA markers based on genomics analysis, for example, the so-called NET test, which has been developed for analyzing gene transcripts in circulating blood; (3) circulating tumor/endothelial/progenitor cells or cell-free tumor DNA, which represent minimally invasive methods that would provide additional information for monitoring treatment response and (4) improved imaging techniques with novel radiolabeled somatostatin analogs or peptides. Below we summarize some future directions in the development of novel diagnostic and predictive/prognostic biomarkers in NENs. This review is focused on circulating and selected tissue markers.
\end{abstract}

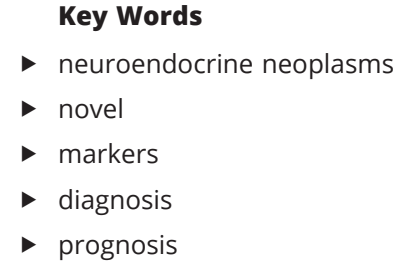

Endocrine-Related Cancer (2019) 26, R157-R179

\section{Introduction}

Neuroendocrine neoplasms (NENs) represent a heterogeneous group of rare neoplasms, which originate from enterochromaffin cells that are located throughout the whole body. NENs located in the gastrointestinal tract and pancreas are also referred to as gastroenteropancreatic neuroendocrine neoplasms (GEP-NENs) (Modlin et al. 2008, Xavier et al. 2016). The annual NENs incidence increases over time, although it is not known whether this is a true increase in NEN incidence, the result of increased use of (improved) diagnostic procedures or a combination of both (Xavier et al. 2016, Dasari et al. 2017).
NENs can be divided into 'functional' and 'nonfunctional' tumors. Functional NENs are able to produce, store and secrete bioactive peptides and can present with specific clinical syndromes related to the biological effects of these substances. Nonfunctional NENs can present with mechanical effects, that is, bowel obstruction or ischemia, but are also frequently discovered by the incidence during diagnostic procedures (Hofland et al. 2018). The clinical course of NENs can be highly variable and includes a spectrum ranging from well-differentiated, indolent growing tumors to 
aggressive, highly proliferative tumors. Around $60-80 \%$ of NENS are metastasized when diagnosed (Modlin et al. $2010 a$ ). The overall 5-year survival rate of patients with NENs ranges between 35 and $82 \%$ in well- to moderately differentiated NENs and between 4 and 38\% in poorly differentiated NENs (Pape et al. 2004, Yao et al. 2008). Survival is specifically determined by several parameters including the localization of the primary tumor (overall 5-year survival: $75.0 \%$ for jejunoileal, $42.9 \%$ for pancreatic NENs), tumor size, presence of vascular invasion, necrosis, surgical resection margin, metastasis, grade and stage of disease (particularly in G1/G2 NENs with localized, regional and distant disease survival rates of 223, 111 and 33 months have been reported respectively; (Pape et al. 2004, Veenendaal et al. 2006, Gao et al. 2018)). Since several factors are involved in NENs patients' survival, the use of nomograms that combine clinical, biochemical, histological and therapeutic characteristics has been proposed (Modlin et al. 2010b, Clift et al. 2017). These nomograms are mostly not validated yet and currently not used in clinical practice. Appropriate standardized diagnostic procedures are required to assure early diagnosis, monitor disease progression and guide an optimal treatment (Oberg et al. 2015). An ideal biomarker should have a high sensitivity for the diagnosis of NENs, to predict tumor clinical behavior and for the response to treatment (Turner et al. 2006). To date, only few diagnostic and therapeutic (reflecting treatment response) markers are available with limited performance, but new biomarkers are in development, including peptides/growth factors, DNA/RNA markers and circulating tumor cells. In this review, we describe the currently available and potential future diagnostic, prognostic and therapeutic biomarkers in NEN, with a focus on circulating factors.

\section{Search strategy}

We searched the Cochrane Library, MEDLINE and EMBASE up to March 2017. Publications from the past 5 years were predominantly selected. The reference lists of articles identified by this search strategy were screened for relevant publications. Commonly cited and important older publications were also included. Some review articles, but especially original articles, were included.

The following search terms, alone or in combination, were used: 'biomarkers', 'novel markers', 'neuroendocrine tumors', 'NETs', 'neuroendocrine neoplasms', 'NENs', 'circulating markers', 'tissue markers', 'therapeutic markers', 'diagnosis', 'chromogranin A', 'neuron-specific enolase', 'N-terminal pro-brain natriuretic peptide', '5-hydroxyindoleacetic acid', 'pancreatic peptide', 'peptides and growth factors', 'DNA markers', 'epigenetic', 'genomic', 'mutations', 'germline', 'somatic', 'alternative lengthening of telomeres', 'whole-genome sequencing', 'chromatin remodeling', 'DNA repair', 'cell-free DNA', 'RNA markers', 'microRNAs', 'somatostatin receptor expression', 'O-6-methylguanine-DNA methyltransferase', 'mTOR pathway inhibitors', 'everolimus', 'temozolamide', 'alkylant-based chemotherapy', 'somatostatin analogs', 'sunitinib', 'immunotherapy', 'molecular biomarkers', 'epidermal growth factor receptor', 'vascular endothelial growth factor', 'Interleukin-8', 'stromal cell-derived factor- $1 \alpha$ ', 'circulating tumor cells', 'endothelial cells', 'white cells', 'placental growth factor', 'tuberous sclerosis complex', 'programmed death-1', 'programmed death-1 ligand'.

\section{Currently available biomarkers for NENs}

Currently used biochemical markers in NENs are usually hormones or amines secreted by NEN cells, which can be influenced by several factors including co-existent disease(s) and drugs, as shown in Table 1 . These biomarkers add to diagnosis, but are insufficient to accurately diagnose NENs, to identify the primary tumor site or to differentiate tumor grading, especially due to sensitivity and specificity issues (Oberg et al. 2015). Despite this, some of them are considered for the diagnosis and follow-up of NENs according to several clinical guidelines as shown in Table 2. In Table 3, a summary of the sensitivity and specificity of currently used biomarkers in NENs is depicted.

\section{Chromogranin A}

Chromogranin A ( $\mathrm{CgA})$ is a protein expressed in the secretory granules of normal and neoplastic neuroendocrine cell types. It is released with peptide hormones and biogenic amines and is also the precursor for functional neuroendocrine peptides (Eskeland et al. 1996, D'Amico et al. 2014). Several guidelines recommend plasma $\mathrm{CgA}$ measurement during diagnosis, treatment and follow-up in GEP-NENs (Table 2). Baseline and serial $\mathrm{CgA}$ may predict clinical outcome, prognosis and tumor response (Arnold et al. 2008) and may be indicative for local progression in patients with liver involvement (Bajetta et al. 1999). Additionally, progressive decrease in CgA levels may be observed in patients with extensive metastatic spread and loss of neuroendocrine differentiation (Zatelli et al. 2007). 
Table 1 Foods, drugs and other conditions which interfere with the results of current NENs biomarkers (Schwartz 1983 Batterham et al. 2003, Jin et al. 2015, Gut et al. 2016).

\begin{tabular}{|c|c|}
\hline Current marker & False-positive results \\
\hline 5-HIAA & $\begin{array}{l}\text { Foods and drinks: Fruits (banana, kiwis, avocado, pineapple, } \\
\text { plums, tomato, aubergine, figs, grapefruit, melon), red wine, } \\
\text { coffee, tea, chocolate, cheese, vegetables (black olives, } \\
\text { spinach, broccoli, cauliflower) } \\
\text { Drugs: Somatostatin analogs, levodopa, methyldopa, heparin, } \\
\text { isoniazid, monoamine oxidase inhibitors, methenamine, } \\
\text { tricyclic antidepressants, phenothiazines, acetylsalicylic acid }\end{array}$ \\
\hline Cg-A & $\begin{array}{l}\text { Foods and drinks: } 30-90 \text { min after a meal } \\
\text { Drugs: Proton pump inhibitors, histamine type-2 receptor } \\
\text { antagonists } \\
\text { Diseases: Atrophic gastritis, pancreatitis, chronic hepatitis, liver } \\
\text { cirrhosis, impaired kidney function, chronic heart failure, } \\
\text { acute coronary syndrome, untreated hypertension, } \\
\text { rheumatoid arthritis, irritable bowel syndrome and } \\
\text { inflammatory bowel disease } \\
\text { Others: Strenuous exercise before the test }\end{array}$ \\
\hline $\begin{array}{l}\text { Pancreatic } \\
\text { polypeptide }\end{array}$ & $\begin{array}{l}\text { Foods and drinks: } 30-90 \text { min after a meal } \\
\text { Diseases: Uncontrolled diabetes mellitus } \\
\text { Others: Increased age, exercise }\end{array}$ \\
\hline
\end{tabular}

\begin{tabular}{l}
\hline False-negative results \\
\hline Drugs: Paracetamol, naproxen, phenacetin, \\
fluorouracil, testosterone, methysergide, \\
acetanilide, reserpine, atenolol, pindolol, \\
oxprenolol, ephedrine, diazepam, \\
methocarbamol
\end{tabular}

Diseases: Low proliferative, rapidly

Proliferating and poorly differentiated NENs

Drugs: Atropine

Diseases: Chronic pancreatitis, pancreatic resection
However, CgA is elevated in only $60-80 \%$ of patients with NENs and has a limited sensitivity of $60-83 \%$ and a relatively low specificity, that is, 72-85\% (Table 3; Schurmann et al. 1992, Bajetta et al. 1999, Seregni et al. 2001, Stivanello et al. 2001, Nehar et al. 2004, Walter et al. 2012, Duque et al. 2013, Wang et al. 2014, Oberg et al. 2017). Moreover, proton pump inhibitors, atrophic gastritis and impaired kidney function can induce a rise in CgA levels (Ardill \& O'Dorisio 2010, Oberg et al. 2017). The combination of CgA with other diagnostic methods, for example, somatostatin receptor scintigraphy, may increase its sensitivity (93\%) and specificity (81\%) (Kalkner et al. 1995, Cimitan et al. 2003, Namwongprom et al. 2008). Importantly, the sensitivity of CgA depends further on the threshold cut-off (Zatelli et al. 2007, Nolting et al. 2012, Oberg et al. 2017), NEN primary location (Baudin et al. 2001, Tomassetti et al. 2001, Nolting et al. 2012), endocrine-associated syndrome (Modlin et al. 2010a), disease spread, liver metastases (Zatelli et al. 2007, Nikou et al. 2008, Nolting et al. 2012, Walter et al. 2012) and the used assay (Ferrari et al. 2004). Despite its use being described in some clinical guidelines, some recent publications suggest a limited applicability as follow-up marker (Marotta et al. 2018). Importantly, different analytical properties of the $\mathrm{CgA}$ kits give different performances, a fact that must be taken into consideration when comparing results from different clinical studies.

\section{Neuron-specific enolase}

Neuron-specific enolase (NSE) is a soluble cerebral protein, which provides information on neural, neuroendocrine

(c) 2019 Society for Endocrinology Published by Bioscientifica Ltd. Printed in Great Britain and paraneuronal cells (Jorgensen et al. 1996). An increase in NSE levels is thought to be related to a high death rate of cells with neuroendocrine differentiation (Bajetta et al. 1999). NSE is probably the most reliable tumor marker in diagnosis, prognosis and follow-up of small-cell lung cancer (SCLC) (Isgro et al. 2015). This marker may be elevated in 38-40\% of GEP-NENs patients, in particular, in those with high-grade tumors (Baudin et al. 1998, van Adrichem et al. 2016b). The specificity of NSE is similar to CgA but with lower sensitivity (Table 3; Grouzmann et al. 1990, Nobels et al. 1997, Baudin et al. 1998). NSE levels have been directly associated with tumor differentiation, aggressiveness and size (Baudin et al. 1998, van Adrichem et al. 2016b). Despite its limited sensitivity, NSE is inversely correlated to overall survival (OS) in ENETS TNM stage IV (van Adrichem et al. 2016b) and with shorter progressionfree survival (PFS), even if CgA levels are normal (Yao et al. 2011).

\section{$\mathrm{N}$-terminal pro-brain natriuretic peptide}

N-terminal pro-brain natriuretic peptide (NT-proBNP) is a peptide produced by myocardial cells in response to electrolyte and fluid balance. Despite it not being a specific NEN marker, its serum concentration is usually elevated in midgut-NENs with a sensitivity of $87 \%$ and a specificity of 80\% (Oberg et al. 2015, Modlin et al. 2016). NT-proBNP is in particular used for evaluating carcinoid heart disease (CHD), and it has been reported that a cut-off value of $260 \mathrm{pg} / \mathrm{mL}$ has a sensitivity of $92 \%$ and specificity of $91 \%$ (Bhattacharyya et al. 2008). Interestingly, it has been 
Table 2 Indications of current biomarkers in GEP-NENs according NCCN 2.2015, NANETS 2010, ESMO 2012, ENETS 2009-2016and UKINETS 2012 guidelines.

\begin{tabular}{|c|c|c|c|c|}
\hline Guideline & CgA & NSE & u-5HIAA & Others \\
\hline $\begin{array}{l}\text { NCCN (Kulke et al. } \\
\text { 2015) }\end{array}$ & $\begin{array}{l}\text { In immunohistochemistry to } \\
\text { establish neuroendocrine } \\
\text { differentiation } \\
\text { For diagnosis (GEP-NENs) } \\
\text { For follow-up (GEP-NENs) }\end{array}$ & & $\begin{array}{l}\text { For diagnosis } \\
\text { (GEP-NENs) } \\
\text { For follow-up } \\
\text { (GEP-NENs) }\end{array}$ & PP: For PNEN diagnosis \\
\hline $\begin{array}{l}\text { NANETS } 2010 \\
\text { (Boudreaux et al. } \\
\text { 2010, Kulke et al. } \\
\text { 2010) }\end{array}$ & $\begin{array}{l}\text { For diagnosis (GEP-NENs, bronchial } \\
\text { NENs**) } \\
\text { For follow-up (GEP-NENs) }\end{array}$ & $\begin{array}{l}\text { Diagnosis bronchial } \\
\text { NENs } \\
\text { Useful for follow-up } \\
\text { (gut-NENs) }^{++}\end{array}$ & $\begin{array}{l}\text { For diagnosis } \\
\text { (GEP-NENs) } \\
\text { For follow-up } \\
\text { (GEP-NENs) }\end{array}$ & \\
\hline $\begin{array}{l}\text { ESMO } 2012 \text { (Oberg } \\
\text { et al. 2012) }\end{array}$ & $\begin{array}{l}\text { For diagnosis (GEP- bronchial -NENs) } \\
\text { For follow-up(GEP-bronchial-NENs) }\end{array}$ & $\begin{array}{l}\text { For bronchial NENs } \\
\text { Value as general } \\
\text { marker }\end{array}$ & $\begin{array}{l}\text { For midgut, } \\
\text { bronchial NENs }\end{array}$ & $\begin{array}{l}\text { PP: For non-functioning } \\
\text { PNEN diagnosis }\end{array}$ \\
\hline $\begin{array}{l}\text { ENETS 2009-2016 } \\
\text { (O'Toole et al. 2009, } \\
\text { Niederle et al. 2016) }\end{array}$ & $\begin{array}{l}\text { For diagnosis (GEP- bronchial -NENs) } \\
\text { For follow-up(GEP-bronchial NENs) } \\
\text { Useful in NEC }\end{array}$ & $\begin{array}{l}\text { NEC diagnosis and } \\
\text { follow-up }\end{array}$ & $\begin{array}{l}\text { For midgut, } \\
\text { bronchial NENs }\end{array}$ & \\
\hline $\begin{array}{l}\text { UKI NETS } 2012 \\
\text { (Ramage et al. 2012) }\end{array}$ & $\begin{array}{l}\text { For diagnosis } \\
\text { For follow-up }\end{array}$ & & $\begin{array}{l}\text { In } \\
\text { bronchopulmonary } \\
\text { and gut-NENs } \\
\text { For follow-up } \\
\text { carcinoid syndrome }\end{array}$ & $\begin{array}{l}\text { NT-proBNP: To rule out } \\
\text { CHD morbidity, midgut } \\
\text { NENs } \\
\text { PP: alternative when } \\
\text { CgA is within the } \\
\text { reference range } \\
\text { NKA: in gut-NENs }\end{array}$ \\
\hline
\end{tabular}

**Suggested. ${ }^{++}$Limited use.

CHD, carcinoid heart disease; ENETS, European Neuroendocrine Tumor Society; ESMO, European Society of Medical Oncology; Gut-NENs include tumors in the jejunum, ileum, appendix, and cecum; NANETS, North American Neuroendocrine Tumor; NCCN, National Comprehensive Cancer Network; NEC, neuroendocrine carcinoma; NKA, neurokinin A; NSE, plasmatic neuron-specific enolase; NT-pro-BNP, N-terminal pro-brain natriuretic peptide; PNEN, pancreatic neuroendocrine neoplasm; PP, pancreatic polypeptide; u-5HIAA, urinary 5-Hydroxy-indolacetic acid; UKI NETS, UK and Ireland Neuroendocrine Tumour Society.

suggested that patients with elevated NT-proBNP levels combined with increased CgA levels have a worse OS when compared to CgA alone (Korse et al. 2009b, Oberg et al. 2015). Importantly, NT-proBNP is not disease specific; thus, further studies for evaluating its applicability in the progression of CHD are still required (Bhattacharyya et al. 2008).

\section{5-hydroxyindoleacetic acid}

Serotonin, produced by (midgut) NENs, is the most prominent hormone associated with diarrhea and flushes in carcinoid syndrome. Its metabolite, 5-hydroxyindoleacetic acid (5HIAA), measured in 24-h urine is used as a diagnostic and follow-up marker (Korse et al. 2009a). Urinary (u) 5HIAA levels are not directly related to the severity of symptoms and large fluctuations within an individual have been described (Zuetenhorst \& Taal 2005). The specificity of 5HIAA is around 90\%, but the reported sensitivity is 35-68\% in patients with NENs (Bajetta et al. 1999, Zandee et al. 2016, Oberg et al. 2017). 5HIAA is mainly used as an indicator of hypersecretory activity in patients with NENs, especially in midgut NENs (Bajetta et al. 1999). Its prognostic value, however, is

(c) 2019 Society for Endocrinology Published by Bioscientifica Ltd. Printed in Great Britain limited. Some studies have related higher urinary 5HIAA levels with mortality (Janson et al. 1997), but these results were not reproduced by other studies (Korse et al. 2009a, Zandee et al. 2016). Its combination with other markers also failed to predict OS and for this reason 5HIAA determination is only recommended to assess carcinoid syndrome (Bhattacharyya et al. 2008).

\section{Pancreatic peptide}

Pancreatic peptide (PP) is a non-specific marker in NENs (Landry et al. 2014). Around 63\% of pancreas NENs (PNENs) and 18-53\% of primary gastrointestinal NENs show increased PP levels (Panzuto et al. 2004). Its determination does not seem to increase the diagnostic performance of other markers like $\mathrm{CgA}$, but changes above 50\% in PP serum levels seem to correlate with tumor increase on imaging (Walter et al. 2012).

\section{Application of currently available biomarkers}

Despite the above-mentioned limitations, current biomarkers are regularly used in clinical practice and their accuracy may increase when combined. Current evidence 
Table 3 Sensitivity and specificity of current and novel neuroendocrine biomarkers.

\begin{tabular}{l}
\hline Tumor marker \\
\hline Chromogranin A (Schurmann et al. 1992, Bajetta et al. 1999, \\
Seregni et al. 2001, Nolting et al. 2012, Duque et al. 2013, Wang \\
et al. 2014, Oberg et al. 2017) \\
Urinary5-HIAA (Bajetta et al. 1999, Zandee et al. 2016, Oberg et al. \\
2017) \\
Pancreatic polypeptide (Panzuto et al. 2004, Metz \& Jensen 2008, \\
Oberg et al. 2015) \\
Neuron-specific enolase (Baudin et al. 1998, Bajetta et al. 1999, \\
Oberg et al. 2015) \\
NT-proBNP (Oberg et al. 2015, Modlin et al. 2016) \\
Pro-GRP (Korse et al. 2011) \\
PNMA2 (Cui et al. 2010) \\
DCR (Edfeldt et al. 2017) \\
TFF3 (Edffeldt et al. 2017) \\
Midkine (Edfeldt et al. 2017) \\
Multritranscript genes (Modlin et al. 2013, Kidd et al. 2015, Bodei \\
et al. 2016)
\end{tabular}

AUC, area under the curve; NDA, no data available.

suggests that circulating CgA levels should be measured at the diagnosis and during follow-up for evaluating disease course and for evaluating treatment response. NSE may be determined for the diagnosis and follow-up of neuroendocrine carcinomas and to predict outcome in NENs. u-5HIAA measurement is valuable for diagnosis, especially in midgut NENs, and when elevated, it should be determined during follow-up in which it might be used in combination with NT-proBNP (O'Toole et al. 2009, Niederle et al. 2016).

Importantly, specific comparisons between markers are difficult since several publications are based on heterogeneous cohorts and retrospective analysis. Additionally, the differences between the used assays limit comparisons and solid conclusions. Notwithstanding, several guidelines recommend these biomarkers for the diagnosis and follow-up in NENs (Table 2).

\section{Potential novel diagnostic biomarkers}

To improve early diagnosis and follow-up of NENs, several new prognostic and treatment-related biomarkers have been developed in recent years (Fig. 1). Most of them are still under study and not yet available for use in clinical practice. It is aimed to develop high-specific and sensitive circulating biomarkers using DNA, RNA and metabolomic approaches. Combination markers and multianalyte analysis may be more effective than the current use of monoanalytes because of a higher sensitivity (Modlin et al. 2013, 2015, Oberg et al. 2015), although validation is still needed. A summary of potential novel circulating and tissue biomarkers for diagnosis, prognosis and

\begin{tabular}{l}
\hline Primary tumor location \\
\hline Non-specific \\
Midgut \\
Pancreas, midgut \\
Non-specific \\
Midgut (non-specific for CHD) \\
Lung \\
SB-NENs \\
SB-NENs \\
SB-NENs \\
SB-NENs \\
GEP-NENs
\end{tabular}

\begin{tabular}{|c|c|}
\hline Sensitivity (\%) & Specificity (\%) \\
\hline $60-83$ & $72-85$ \\
\hline $35-68$ & $90-100$ \\
\hline $31-63$ & $\sim 67$ \\
\hline 33 & 73 \\
\hline 87 & 80 \\
\hline 43 & 99 \\
\hline 46-50 & NDA \\
\hline AUC: 0.74 & \\
\hline AUC: 0.72 & \\
\hline AUC: 0.71 & \\
\hline 75-98 & \\
\hline
\end{tabular}

therapy response prediction, as well as their relation with tumor localization, is shown in Fig. 2. Herein we describe the potential applicability of novel peptides/growth factors, DNA, RNA and therapeutic markers for NENs, in particular, circulating biomarkers.

\section{Peptides and growth factors}

Several peptides and growth factors (Table 4) have been studied for a (potential) role as biomarker in NENs and may (1) help to localize primary tumors (e.g. progastrinreleasing peptide in lung NENs, connective tissue growth factor (CCN2), paraneoplastic Ma antigen 2, DcR3, TFF3 and midkine in small intestine NENs (Bergestuen et al. 2010, Korse et al. 2011, Oberg et al. 2015, Edfeldt et al. 2017)); (2) predict the outcome in functioning NENs (e.g. $\alpha$-Internexin in insulinomas (Schimmack et al. 2012, Liu et al. 2014)) or predict early complications in patients with CHD (CCN2 (Bergestuen et al. 2010)) and (3) add information to that provided by other circulating/tissue markers for treatment response evaluation and outcome prediction (e.g. pro-GRP and CgA for predicting outcome/ therapeutic response in lung carcinoids; $\alpha$-Internexin in combination with Ki67 for aggressiveness prediction in insulinomas (Grabowski et al. 2005, Korse et al. 2011, Fotouhi et al. 2016, Fujino et al. 2016) or as part of multianalytes tests (Edfeldt et al. 2017)).

Although imaging markers are not described in this review, it is important to mention that some peptides may be useful to correlate with imaging techniques. For instance, glucose transporter 1 (GLUT1) expression in NENs is associated with the Ki67 index and 


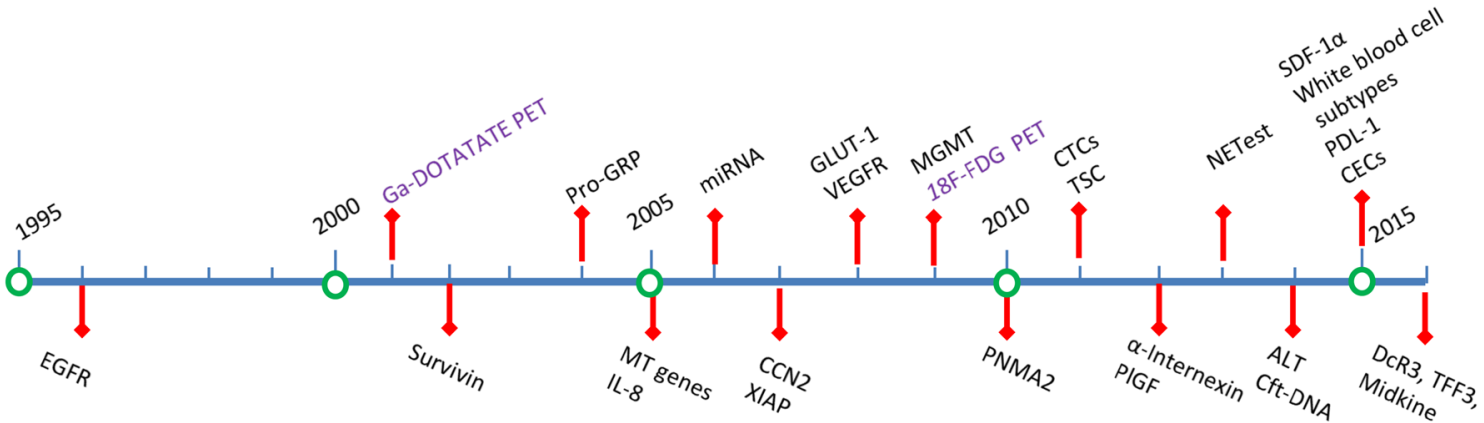

\section{Figure 1}

Timeline of the publication of potential novel biochemical and therapeutic markers in neuroendocrine neoplasms during the last two decades. Monoanalytes, transcripts, DNA-, RNA- immune- markers are shown, mostly are still under study and not available for use in clinical practice. Imagebased modalities are represented in purple. 18F-FDG PET, 18fludeoxyglucose positron emission tomography; ALT, alternative lengthening of telomeres; CCN2, connective tissue growth factor; CECs, circulating endothelial cells cftDNA, circulating cell-free tumor DNA; CTCs, circulating tumor cells; EGFR, epidermal growth factor receptor; GLUT-1, glucose transporters type 1; IL-8, interleukin 8; MGMT, O-6-methylguanine-DNA methyltransferase; miRNA, microRNA; MT, multitranscript; PD-L, programmed death ligand-1; PIGF, Placental growth factor; PNMA2, paraneoplastic Ma antigen 2; proGRP, progastrin-releasing peptide; SDF-1 $\alpha$, stromal cell-derived factor $1 \alpha$; TSC, Tuberous sclerosis complex; VEGFR, vascular endothelial growth factor receptor; $\mathrm{XIAP}, \mathrm{X}$-linked inhibitor of apoptosis. Imaging techniques, as reference, are presented in purple.

18-fluorodeoxyglucose (FDG) uptake at FDG-positron emission tomography (PET) scans (Binderup et al. 2013). GLUT-1 expression may serve as an additional marker for aggressiveness of NENs and may add to a more accurate grading (Binderup et al. 2013).

Although some of these peptides have been suggested as promising biomarkers, most of them are non-specific. In addition, their applicability is limited, due to their sensitivity and specificity (Table 3 ) and the absence of appropriate cut-off levels. In addition, some of them have been described only in single retrospective studies; thus, further validation in larger and longitudinal cohorts is still required. A summary of potential peptide/growth factors markers for NENs is described in Table 4.

\section{Genetic and epigenetic markers}

Generally, tissue and circulating tumor DNA markers may provide information on the genetic characteristics of the tumor which may result in better prediction of clinical

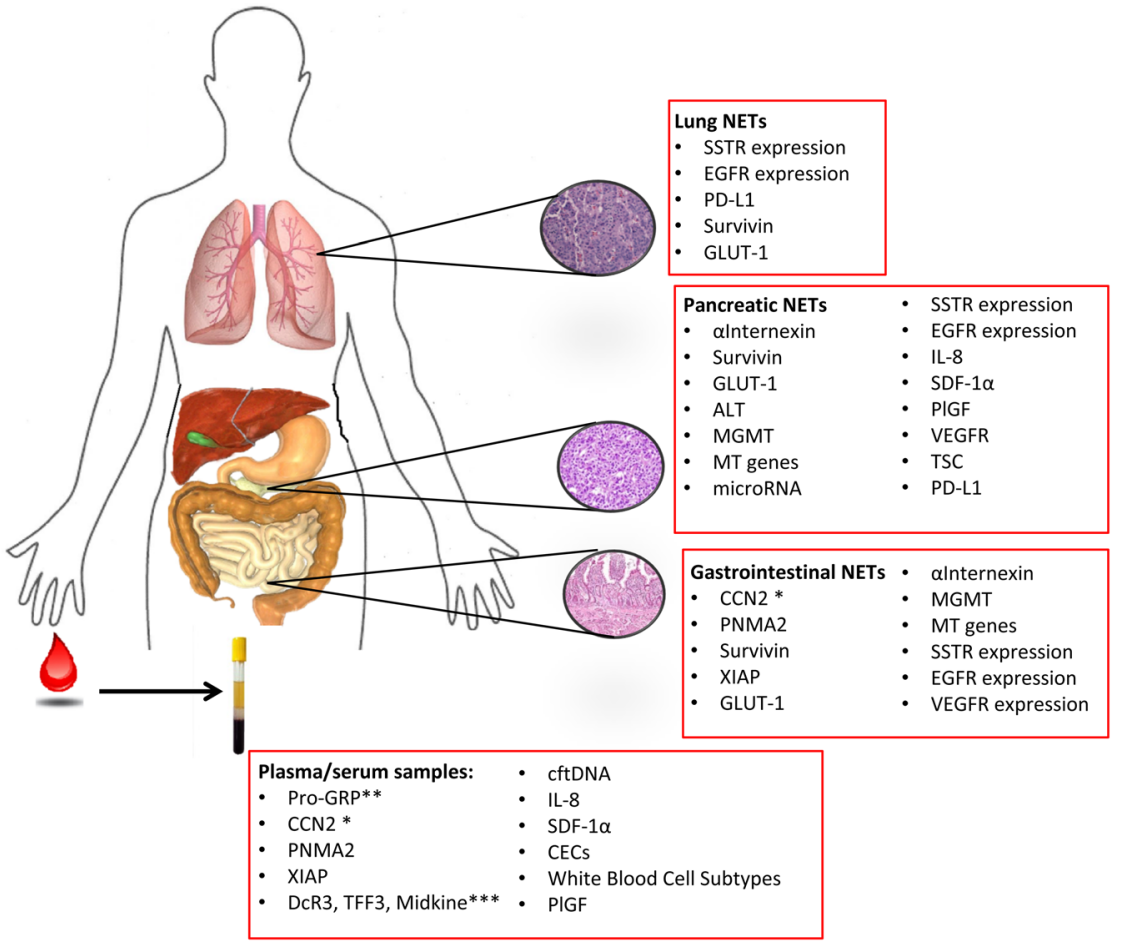

Figure 2

Summary of potential novel diagnostic and therapeutic markers in neuroendocrine neoplasms. Several tumor or plasma/serum biomarkers seem to play a role in the diagnosis or follow-up in lung and GEP-NENs. Its presence may be determined in serum or tissue samples. Please refer to the text for explanation of each tumor marker. *specific for carcinoid heart disease; ** only for lung NENs; ***only for small intestine NENs; ALT, alternative lengthening of telomeres; CCN2, connective tissue growth factor for carcinoid heart disease; CECs, circulating endothelial cells; cftDNA, circulating cell-free tumor DNA; EGFR, epidermal growth factor receptor; GLUT-1, glucose transporters type 1; MGMT, O-6-methylguanine-DNA methyltransferase; MT, multitranscript; PD-L, programmed death ligand-1; PIGF, placental growth factor; PNMA2, paraneoplastic Ma antigen 2; proGRP, progastrin-releasing peptide; SDF- $1 \alpha$, stromal cell-derived factor $1 \alpha$; SST, somatostatin; TSC, tuberous sclerosis complex; VEGFR, vascular endothelial growth factor receptor; XIAP, X-linked inhibitor of apoptosis. (c) 2019 Society for Endocrinology Published by Bioscientifica Ltd. Printed in Great Britain 
Table 4 Peptides and growth factors as novel markers in NENs.

\begin{tabular}{l} 
Peptide/growth factor \\
\hline Progastrin-releasing peptide \\
(proGRP)
\end{tabular}
for carcinoid heart disease (CCN2)

Paraneoplastic Ma antigen 2 (PNMA2)

\author{
$\alpha$-Internexin \\ X-linked inhibitor of apoptosis \\ (XIAP)
}

Glucose transporters type 1 (GLUT-1)

DcR3

TFF3

Midkine

\begin{tabular}{l} 
Function \\
\hline Precursor of gastrin-releasing peptide, a \\
neuropeptide hormone widely distributed \\
throughout the gastrointestinal and pulmonary \\
tract (McDonald et al. 1979)
\end{tabular}

CCN2 is an early gene product of the CCN family of matricellular proteins, which are involved in cell proliferation, angiogenesis, tumorigenesis and wound healing. It may be involved in the pathogenesis of carcinoid heart disease (Holbourn et al. 2008, Bergestuen et al. 2010)

Antineuronal antibodies identified as markers of neurological paraneoplastic syndromes (Schuller et al. 2005)

Cytoskeleton protein involved in tumorigenesis and disease progression (Nathke 2006)

Inhibitor of apoptotic cell death in cancer cells (Mihaly et al. 2014, Obexer \& Ausserlechner 2014)

Mediates the transport of glucose across the cellular membrane and are commonly overexpressed in tumors, probably related with higher metabolism and cell growth (Clavo et al. 1995)

Regulates cytokines which influence tumor growth and reduce apoptotic stimuli (Lin \& Hsieh 2011)

Protects and repairs epithelial surfaces Enhances migration, angiogenesis, and inhibits apoptosis (Vestergaard et al. 2010, Casado et al. 2012, Huang et al. 2013)

Promotes tumor cells migration, angiogenesis and reduces apoptosis (Jones 2014)

\section{Potential role as marker in NENs \\ Primary tumor localization in patients with a metastatic NEN of unknown origin. \\ Complementary marker to CgA in lung NEN for treatment response evaluation and survival (Korse et al. 2011, 2015) \\ Independent predictor of both reduced right ventricular function and right- sided valve regurgitation (its plasma levels are inversely related to right ventricular function levels) \\ Early predictor of cardiac fibrosis (Bergestuen et al. 2010) \\ Allows the identification of almost 50\% of SB-NENs at the primary stage of the disease \\ Correlation with disease progression and recurrence free survival (Cui et al. 2010)}

Association with proliferation, ki67 index and malignancy (Schimmack et al. 2012)

Potential target therapies (Yap et al. 2011, Cingarlini et al. 2012, Augeri et al. 2016)

Predictor of risk of death in neuroendocrine lung carcinomas and lung carcinoids (Ozbudak et al. 2009)

Relation with Ki67 index in GEP- and lung NENs (Binderup et al. 2013, Benzerdjeb et al. 2017)

Correlation with the uptake in 18-FDGPET (Binderup et al. 2013)

DcR3 correlates to liver metastasis and worse survival

Predictor of treatment resistant tumors (Edfeldt et al. 2017)

Higher concentrations have been correlated to reduced survival (Edfeldt et al. 2017)

Predictive marker to chemotherapy response(Hu et al. 2010, Wu et al. 2015) outcome and could aid in clinical decision making (Modlin et al. 2014b). The possibility of performing liquid biopsies is expected to anticipate malignancy of solid lesions in a non-invasive way, but it is still necessary to optimize the detection technique, analysis and interpretation.

An example of a tissue DNA prognostic marker for NENs involves alternative lengthening of telomeres (ALT). A telomerase-independent mechanism to avoid the chromosome end replication was suggested in tumor cells, and in this context, ALT was reported in liver metastasis of NENs (Dogeas et al. 2014). In PNENs, whole-exome sequencing studies have demonstrated that inactivating mutually exclusive mutations in X-linked transcriptional regulator $(A T R X)$ and death domain-associated protein 6
(DAXX) genes (Jiao et al. 2011) are associated with the ALT (Heaphy et al. 2011, Schwartzentruber et al. 2012). However, results on its relationship with clinical features are inconclusive and in some cases contradictory. In this sense, ALT-positive PNENs have been associated with larger tumor size, grading, vascular/perineural invasion and metastasis (Marinoni et al. 2014, Kim et al. 2017). In addition, an increased risk of recurrence and decreased OS has been reported in ALT-positive NEN metastasis (Marinoni et al. 2014, Kim et al. 2017). In contrast, other authors found an association with better clinical outcomes (Jiao et al. 2011, Dogeas et al. 2014) including metastatic disease (Kim et al. 2017). Since it is possible to determine ALT, ATRX and DAXX using fine-needle https://erc.bioscientifica.com

https://doi.org/10.1530/ERC-18-0354 (c) 2019 Society for Endocrinology Published by Bioscientifica Ltd. Printed in Great Britain 
aspiration (FNA), they may be used as minimally invasive prognostic markers in NENs (VandenBussche et al. 2017), but their clinical significance should still be evaluated in detail.

Additionally, whole-genome sequencing in NENs allow the identification of genomic events related with tumor pathogenesis. In this sense, germline deleterious mutations affecting DNA damage repair in PNENs have been described (in the base-excision-repair MUTYH gene or the homologous recombination gene BRCA2) (Scarpa et al. 2017). Furthermore, mutations in genes involved in chromatin remodeling, DNA repair and mTOR signaling may also play a role in PNEN pathogenesis (Scarpa et al. 2017). Several publications have also shown chromosome losses affecting genes related to DNA repair or damage checkpoints (VHL, MEN1, ATM, PTEN) in PNENs (Capurso et al. 2012, Scarpa et al. 2017). In this sense, most recent reviews describe genetic alterations that are consistently related with the loss of MEN1 function, the activation of the PI3K/mTOR pathway, changes in chromatin remodeling and telomeres alteration (Mafficini \& Scarpa 2018).

Importantly, somatic mutations and deletions have also been described in midgut NENs, specifically in the cyclin-dependent kinase inhibitor gene CDKN1B. This finding suggests that the p21/p27/p57 family, which is involved in the cell cycle, may also be involved in the pathogenesis of small-bowel NENs (Francis et al. 2013). Genetic alterations in PNENs are extensively reviewed in a recent publication by Stevenson and colleagues (Stevenson et al. 2018).

Cell-free DNA (cftDNA) from liquid biopsies may become a biomarker in NENs, although to date, no studies have been published yet on the detection of cftDNA in NENs. cftDNA generally contains identical genetic defects as the primary tumor (Diaz \& Bardelli 2014), is released after apoptosis (Francis \& Stein 2015) and can be detected in serum (Marzese et al. 2013, Rothe et al. 2014). The analysis of cftDNA may be useful for early detection of (residual or recurrent) disease, to monitor tumor burden, to assess molecular heterogeneity and to predict PFS (Francis \& Stein 2015), especially in adenocarcinomas (Francis \& Stein 2015). Measurement of cftDNA might be a promising tool in NENs, but needs further investigation (Rizzo \& Meyer 2018). The ultimate aim of cftDNA assessment would be to add to or replace tissue biopsies (Khan et al. 2013, Sikora et al. 2015). Prerequisites for cftDNA analysis are sufficient tumoral DNA release and the presence of tumor-related mutations to identify tumor DNA. These conditions may only be present in a subset of
NEN patients, thereby limiting the applicability of cftDNA measurement. Further study is needed to determine the potential role of cftDNA analysis in NEN.

A summary of genetic markers in NENs is shown in Fig. 3.

\section{RNA markers}

RNA markers are novel and potentially promising minimally invasive markers used for diagnostic purpose and/or to identify the therapeutic targets of NENs. Specifically, the identification of circulating target gene mRNAs using PCR amplification has been used for determining stage, prognosis, recurrence or new metastasis in several cancers (van't Veer et al. 2002, Frederiksen et al. 2003, Hess et al. 2006). Blood circulating- and tumor tissuetranscripts from GEP- and bronchopulmonary NENs are highly correlated (Cwikla et al. 2015, Kidd et al. 2015). Modlin et al. have developed a PCR-based molecular test using 51 genes for identifying GEP-NENs (Modlin et al. 2013). For this so-called NETest, a score, based on tissue and peripheral blood transcriptomes, was developed (Modlin et al. 2013) as a prognostic and follow-up tool for NENs (Modlin et al. 2013, 2014a, 2015, Kidd et al. 2015). NETest results were shown to differentiate progressive disease (Kidd et al. 2015) and predict tumor response to somatostatin analogs (SSAs) (Cwikla et al. 2015). Further prospective validation of this test is awaited.

Additionally, dysregulated miRNAs have been correlated with diagnosis, staging, progression, prognosis and therapeutic response in several tumors, including NENs (Di Leva \& Croce 2013). miRNAs are endogenous, small (19-25 nucleotides), non-coding RNAs that regulate post-transcriptional gene expression by binding to mRNA molecules, and they probably modulate the expression of at least one-third of protein-coding genes (Demes et al. 2016). miRNAs have the capacity to target different genes implicated in the same pathway and/or in interacting pathways, allowing for the possibility of developing directed therapies that could silence several tumor pathways (Reddy 2015).

Specific patterns of miRNA expression may distinguish tumor tissue from normal tissue and acinar tumors from PNENs (Roldo et al. 2006, Vicentini et al. 2014). Some miRNAs are upregulated in PNENs (miR-140, miR-210), small-bowel (SB-)NENs (miR-96, miR-182, miR-183, miR196a, miR-200a) and lung carcinoids (mMR-34a) (Li et al. 2013, Demes et al. 2016). Also, the downregulation of miRNA-133a, miRNA-1 and miRNA-143-3p has been demonstrated in metastasis when compared to the 


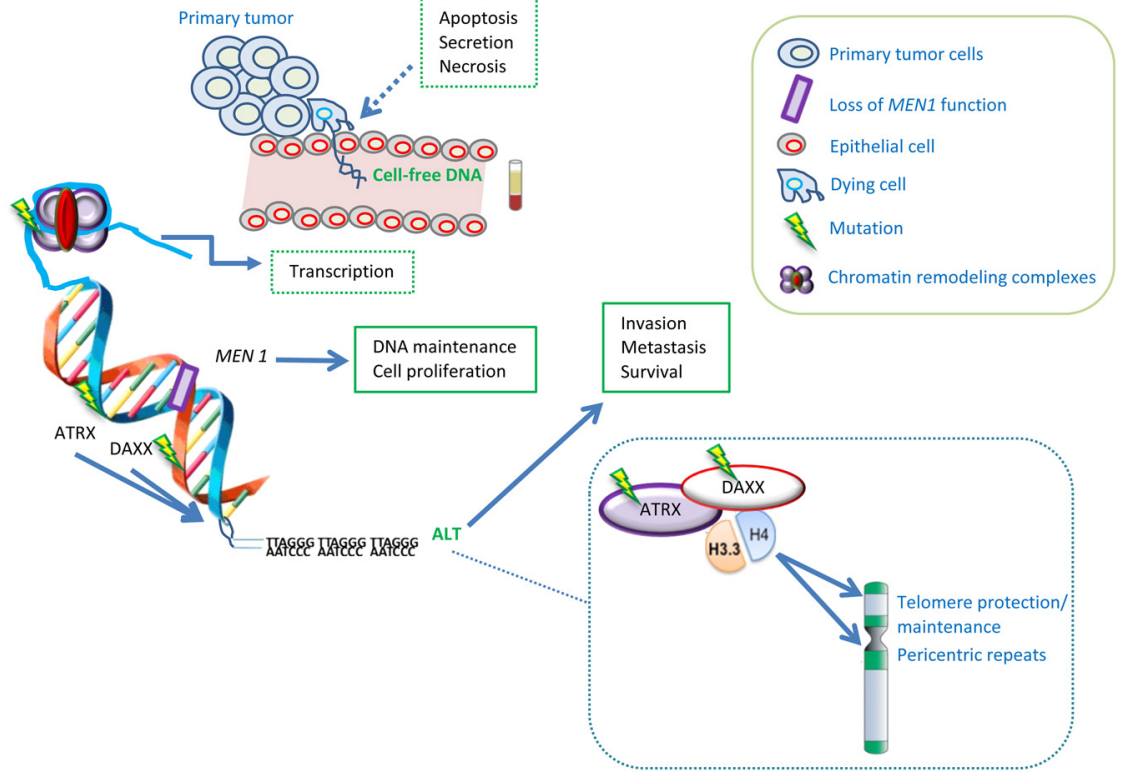

\section{Figure 3}

Summary of genetic markers in pancreatic neuroendocrine neoplasms. Genetic markers are presented in green. Tumor cells release small fragments of cftDNA into circulation by multiple mechanisms, cftDNA contains identical genetic defects compared to the primary tumor. Mutations affecting chromatin remodeling and MEN1 function may be related to tumor proliferation. Inactivating mutations in ATRX and DAXX genes are associated with ALT. ALT, alternative lengthening of telomeres; ATRX, $X$-linked transcriptional regulator; cftDNA, cell-free tumor DNA; DAXX, death domainassociated protein 6 . primary NEN tumor (Ruebel et al. 2010, Miller et al. 2016). As prognostic marker, miRNA levels have been correlated with Ki-67 (Thorns et al. 2014, Arvidsson et al. 2018), degree of malignancy (e.g. miR-21 in PNENs; miR-13/ miR-204-5p in SB-NENs) (Demes et al. 2016, Arvidsson et al. 2018) and OS (e.g. the downregulation of miR-375 in SB-NENs (Arvidsson et al. 2018)).

miRNAs may also be used for therapeutic goals, for example, inhibition of oncogenic miRNA expression or the introduction of a tumor suppressor miRNA (Vicentini et al. 2014). However, the currently available technology is not robust enough to support diagnostic or therapeutic use of miRNAs yet (Oberg et al. 2016). Furthermore, dysregulation of miRNAs is not tumor specific and the absence of cut-off levels for differentiating tissue and tumor subtypes, the lack of reproducibility in other NEN cohorts and the difficulties in their interpretation, currently limit their clinical application. Further studies are required to evaluate the application of miRNAs as clinical and therapeutic markers in NENs. This issue is extensively reviewed in recent publications (Zatelli et al. 2017, Zimmermann et al. 2018, Rizzo \& Meyer 2018, Panarelli et al. 2019).

\section{Potential novel diagnostic-therapeutic biomarkers}

Some (potential) circulating and tissue therapeutic markers are available in NENs. To a certain extent, the currently available markers CgA and NSE can be used for treatment monitoring. Variations in serum CgA levels after treatment with SSAs and PRRT have been reported. Specifically, decreased CgA in stable/responsive tumors has been observed (Caplin et al. 2014, van der Zwan et al. 2015), but serum CgA may also increase (>20\%) due to radiation-induced cell damage or lysis after the first cycle of PRRT. In the latter case, this increase was followed by declined levels usually after 12 weeks (Brabander et al. 2017). Furthermore, tumor shrinkage has been associated with CgA or NSE response after treating patients with everolimus (increased PFS in patients with early CgA/NSE response) (Li et al. 2011). However, specific cut-off values to define response to different treatment modalities have not been determined yet and novel/specific therapeutic biomarkers are still required. A summary of clinical applicability of novel biomarkers in NENs is presented in Table 5.

\section{Somatostatin receptor expression}

Somatostatin receptor (SST) expression by NENs, in particular subtype 2, is used for imaging to diagnose and stage NENs (Wong et al. 2012) and is considered to have therapeutic implications for treatment with SSAs and PRRT with radiolabeled somatostatin analogs as Lutetium-177- or Yttrium-90-coupled analogs (Kwekkeboom et al. 2010, Strosberg et al. 2017). SST expression as imaging marker is not described in this review, but it has been comprehensively evaluated in several publications (de Herder et al. 2006, Kwekkeboom et al. 2010, Kunikowska et al. 2017, Bodei \& Weber 2018, Hope et al. 2018).
(C) 2019 Society for Endocrinology Published by Bioscientifica Ltd. Printed in Great Britain 
SST can also be evaluated in NEN tissue samples using immunohistochemistry and qPCR (Fig. 4; Righi et al. 2010, Mizutani et al. 2012, Lambertini et al. 2013, Kanakis et al. 2015, Herrera-Martinez et al. 2017, 2018). SST expression may help to differentiate normal and tumor tissue in lung carcinoids and GEP-NENs and has been related to vascular/nerve invasion and metastasis (Herrera-Martinez et al. 2017, 2018). The tumor SST expression profile may also be helpful for predicting treatment response (Reubi et al. 2010, Righi et al. 2010), especially in aggressive cases (Righi et al. 2010). On the other hand, the immunohistochemical assessment of NEN tissue expression of SST subtype 2 had no additional value compared to the uptake on the OctreoScan in predicting tumor response after PRRT (Korner et al. 2012, Bison et al. 2014, van Adrichem et al. 2016a). The tumoral expression of SST3 and SST5 may also be a relevant marker supporting the potential benefit of novel SSAs. Truncated isoforms of SST can also be expressed by NENs, and their presence is associated with aggressive features

Table 5 Clinical applicability of potential new biomarkers in NENs.

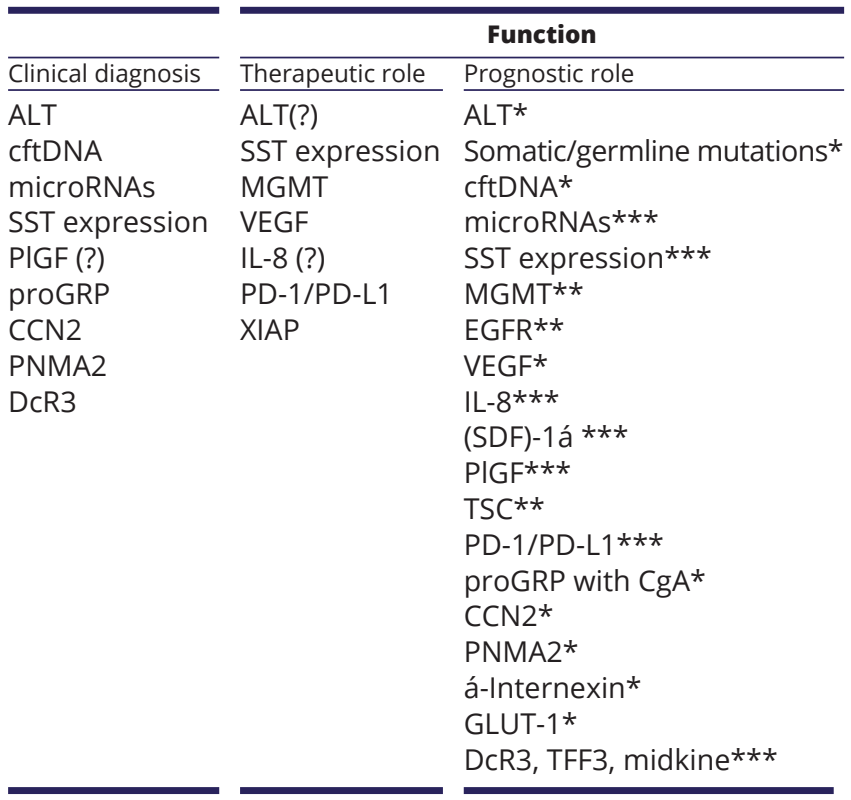

*Disease course predictor; **Intervention outcome predictor; ***Disease and treatment predictor.

ALT, alternative lengthening of telomeres; CCN2, connective tissue growth factor for carcinoid heart disease; cftDNA, cell-free DNA; CTCs, circulating tumor cells; EGFR, epidermal growth factor receptor; GLUT-1, glucose transporters type 1; IL-8, interleukin-8; MGMT, 0-6-methylguanine-DNA methyltransferase; PD-1, programmed death-1; PD-L1, programmed death ligand 1; PIGF, placental growth factor; PNMA2, paraneoplastic Ma antigen 2; proGRP, progastrin-releasing peptide; SDF-1 $\alpha$, stromal cell-derived factor- $1 \alpha$; SST, somatostatin receptor; VEGF, vascular endothelial growth factor; XIAP, X-linked inhibitor of apoptosis.

C) 2019 Society for Endocrinology Published by Bioscientifica Ltd. Printed in Great Britain
(Sampedro-Nunez et al. 2016). Unfortunately, results are based on retrospective heterogeneous cohorts, which may limit the reproducibility. Additionally, in some of the above indicated studies, SST expression by qPCR was determined in formalin-fixed paraffin embedded tumors, which may affect the expression profile in some samples (Sampedro-Nunez et al. 2016, Herrera-Martinez et al. 2017, 2018).

\section{0-6-methylguanine-DNA methyltransferase (MGMT)}

An example of a tissue DNA therapeutic marker for NENs is the methylation pattern of the DNA repair enzyme O-6-methylguanine-DNA methyltransferase (MGMT). Several agents have antitumor effects by inducing DNA methylation at the $\mathrm{O} 6$ position of guanine, resulting in apoptosis and tumor cell death (Liu \& Gerson 2006). Those lesions can be restored by MGMT, reduction of which may increase the sensitivity of tumor cells to alkylation-induced DNA damage (Christmann et al. 2011). The methylation of MGMT promoter and loss of MGMT protein expression have been reported in GEP-NENs (Walter et al. 2015). Decreased MGMT expression has been associated to tumor sensitivity to alkylant-based chemotherapy agents, for example, temozolomide, alone or in combination therapy (Gerson 2002). In PNENs, absence of MGMT is more common compared to intestinal or lung carcinoids, which explains the better treatment response in PNENs to temozolomide (Kulke et al. 2009, Schmitt et al. 2014).

Further, a 'hypermethylator' phenotype, which is characterized by the presence of a high number of methylated genes, has been associated with more progressive disease and shorter survival (Walter et al. 2015), whereas this association was not found in welldifferentiated PNENs (Raj et al. 2017). The predictive value of MGMT status for treatment response in NENs will be evaluated in clinical trials with alkylating agents (NCT03217097).

\section{Molecular biomarkers for treatment with tyrosine kinase inhibitors (TKIs)}

In patients with advanced, well-differentiated, progressive PNENs, sunitinib can induce tumor stabilization and improve PFS. Currently, sunitinib is used for progressive disease, but its combination with SSAs, chemotherapeutic agents or neo-adjuvant or adjuvant therapy in earlier stages of resectable PNENs has also been proposed (Delbaldo et al. 2012, Mateo et al. 2012). The possibility to peripherally measure monoanalytes directly related to 

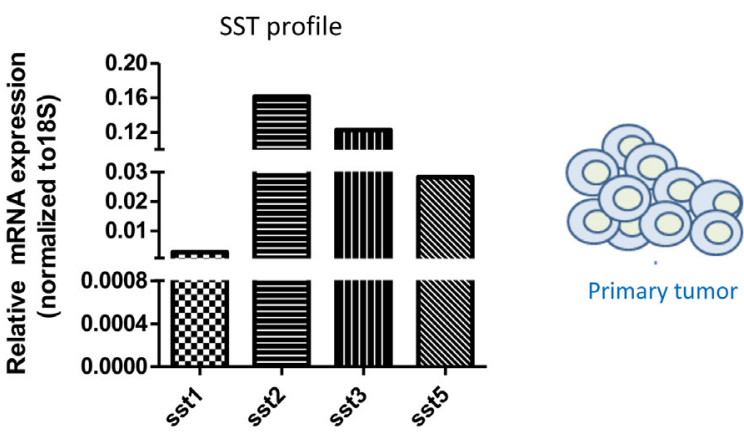

Primary tumor

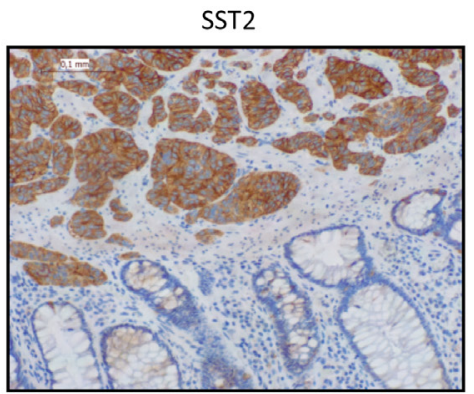

\section{Figure 4}

Somatostatin receptors expression for diagnosis. SST expression may be determined in tumor using immunochemistry (sst2 immunostaining in a GEP-NEN; right panel) and/or RT-qPCR (SST subtype mRNA profile in an exemplary GEP-NEN; left panel). Both results may be used for treatment decisions but also to predict outcome. SST, somatostatin.

the drug mechanism of action represents an important approach to predict treatment response; in this sense, some molecular biomarkers have been examined in the last years.

\section{Epidermal growth factor receptor}

The epidermal growth factor receptor (EGFR) is overexpressed in non-small-cell lung cancer and an increased sensitivity to the TKIs erlotinib and gefitinib has been reported when the tyrosine kinase domain of the EGFR has somatic mutations (Paez et al. 2004). EGFR expression by immunohistochemistry was demonstrated in $21-28 \%$ of typical carcinoids, $29-57 \%$ of atypical lung carcinoids (Rusch et al. 1996, Rickman et al. 2009) and in $40-96 \%$ of NENs, while its gene amplification by fluorescent in situ hybridization was observed in 55\% of cases (Srivastava et al. 2001, Shah et al. 2006, Rickman et al. 2009, Gilbert et al. 2010). In addition, activating EGFR mutations have been described in NENs and may be associated with improved treatment response (Costanzo et al. 2013, Aroldi et al. 2014). Importantly, EGFR mutations are rare in GEP-NENs, and their clinical relevance may be limited as compared with other tumors including lung adenocarcinoma (Park et al. 2016). The specific clinical significance of the expression of EGFR, however, is still to be determined.

\section{Vascular endothelial growth factor receptor}

Vascular endothelial growth factor (VEGF) is the most important regulatory factor of tumor angiogenesis and has been related to cell survival, growth and metastasis (Niu \& Chen 2010). VEGF may be determined in tumor and in FNA samples (Angelescu et al. 2013). In general, well-differentiated GEP-NENs express high levels of VEGF and its transmembrane receptors ((VEFGR-1, VEFGR-2,
VEFGR-3) (Pavel et al. 2005)), which can be detected in peripheral blood (Mateo et al. 2012). In this context, a worse clinical course has been reported in NENs with increased VEGF expression (Terris et al. 1998, Pavel et al. 2005, Zhang et al. 2007, Yao et al. 2011). Immunohistochemical and molecular expression of VEGFR-1/-2 has been reported in over 50\% of GEP-NENs (La Rosa et al. 2003, Angelescu et al. 2013) without being directly related to tumor malignancy (La Rosa et al. 2003).

Some relations between VEGFR and patient outcome have been described; specifically, low VEGFR-1 levels have been related to longer PFS (Yao et al. 2012), high baseline VEGFR-2 levels to decreased OS in PNENs (Zurita et al. 2015) and low VEGFR-3 levels to longer PFS/OS in carcinoid patients (Zurita et al. 2015). Increased VEGF concentrations accompanied by decreased VEGFR-2 and VEGFR-3 levels have been reported after treatment with sunitinib (Deprimo et al. 2007), but their levels returned to baseline during the off-treatment period (Zurita et al. 2015). Unfortunately, VEGFRs are not tumor specific; additionally, cut-off levels are also necessary to predict outcome. The applicability of VEGFR-1 as a therapeutic predictive marker is currently considered in clinical trials (pazopanib in advanced NENs, NCT01280201), but further studies are still required.

\section{Interleukin-8}

Interleukin-8 (IL-8) has proangiogenic, mitogenic and motogenic effects through the activation of the receptors CXCR1 and CXCR2 (Mateo et al. 2012). PNENs overexpress not only IL-8 but also its receptor CXCR2 (Tecimer et al. 2000, Hussain et al. 2010). IL-8 seems to be increased in progressive NENs, while lower IL-8 baseline levels have been associated with longer survival (Pavel et al. 2005). Patients with SB-NENs and lower IL-8 levels were shown to (c) 2019 Society for Endocrinology Published by Bioscientifica Ltd. Printed in Great Britain 
have disease stabilization or clinical response to sunitinib (Bello et al. 2006). It has also been hypothesized that monitoring IL-8 in plasma during sunitinib treatment could be useful to predict drug resistance (Huang et al. 2010), but this needs further investigation.

\section{Stromal cell-derived factor (SDF)-1 $\alpha$}

SDF- $1 \alpha$ plays a role in cell migration, proliferation, survival and angiogenesis (Mateo et al. 2012) and is the natural ligand of CXCR4. CXCR4 has been reported in several cancer types (Balkwill 2004), seems to be involved in tumor progression, metastasis, hypoxia adaptation and stem cell survival (Kaemmerer et al. 2015) and may serve as a marker of tumor activity and progression (Zurita et al. 2015). SDF-1 $\alpha$ expression seems to be increased in PNENs compared to other NENs and is inversely correlated with time to disease progression (Zurita et al. 2015). In addition, it has been described as a circulating biomarker associated with tumor response to sunitinib (Antonuzzo et al. 2013). Arvidsson and collaborators described downregulation of SDF-1 $\alpha$ and upregulation of CXCR4 in hypoxic carcinoid cells with consequently higher cell migration, probably due to the activation of the mitogen-activated protein kinase pathway. Based on this, a putative role in antiangiogenic drugs resistance was also suggested, and SDF- $1 \alpha$ may serve as a therapeutic target (Arvidsson et al. 2010).

\section{Circulating tumor, endothelial and white cells}

Circulating tumor cells (CTCs) have been widely used in several tumors as peripheral blood tumor markers (Cristofanilli et al. 2005, Cohen et al. 2008, Resel Folkersma et al. 2012). The identification of cellular expression of the epithelial cell adhesion molecule (EpCAM) allowed the determination of CTCs in NENs (Modlin et al. 2016), in which a threshold of 1 CTC (similarly to breast cancer) was demonstrated (Khan et al. 2011). CTCs have been associated with higher tumor grade and burden, increased circulating CgA, Ki67 index and worse PFS and OS in grade 1-2 NENs (Khan et al. 2011, 2013). Measurement and molecular characterization of CTCs may be helpful to stratify patients for specific therapies in the future (Khan et al 2011, Zatelli et al. 2017). However, the sensitivity of CTCs varies according to the NEN type, and CTCs are not specific for any subgroup of tumors (Oberg et al. 2015).

Additionally, circulating endothelial cells (CECs) were also described in NENs, specifically two different subpopulations: endothelial precursors derived from the bone marrow (CEPs) and mature CECs (Nolan et al. 2007).
Increased circulating CECs have been related to vessel damage during antiangiogenic treatment and consequently with a longer PFS (Beaudry et al. 2005). Theoretically, CEPs should decrease after anti-VEGF therapy (Kalka et al. 2000); but in contrast, decreased CECs and stable CEPs were observed in NENs after the first cycle of treatment with sunitinib (Zurita et al. 2015).

Moreover, myeloid cells have been related to angiogenesis, disease progression, metastasis and the expression of some receptors related with the VEGF and SDF- $1 \alpha$ pathways in other tumors (Fernandez Pujol et al. 2000, Condeelis \& Pollard 2006). Zurita et al. described decreased CD14+ monocytes expressing VEGFR-1 and CXCR4 in NENs treated with sunitinib. It has been postulated that possible relations exist between specific monocyte subpopulations and drug pharmacodynamics, which would be useful as a treatment response predictor (Zurita et al. 2015). Because of the heterogeneity of the included patient samples (grading, previous treatments and origin of primary tumor), results remain controversial (Antonuzzo et al. 2013). Currently, there is no consensus for supporting the use of CTCs or CECs as an indicator of tumor burden or parameter of treatment response in NENs (Oberg et al. 2016). Further prospective, longitudinal studies in this field are still required. A summary of current tumor biomarkers for TKIs is shown in Fig. 5.

\section{Molecular biomarkers for mTOR pathway inhibitors}

Increased PFS has been described in patients with advanced metastatic PNENs treated with the mTOR pathway inhibitor everolimus (Yao et al. 2010, Pavel et al. 2011). Although the combination of everolimus and SSAs does not seem to increase OS, the heterogeneity of the included patients makes these results inconclusive (Pavel et al. 2017). Based on this, it would be valuable to develop markers that could early identify those patients who may benefit from everolimus alone or in combination with SSAs.

In this sense, placental growth factor (PlGF) has been related to angiogenesis, tumor burden, presence of metastases and survival (Carmeliet et al. 2001, Fischer et al. 2008) and is thought to reflect the activation of AKT and ERK pathways (Parr et al. 2005, Fischer et al. 2008, Wei et al. 2009). Elevated levels of circulating PlGF have been demonstrated in PNENs, with increasing levels from grade 1 to grade 3 tumors (Hilfenhaus et al. 2013). Decreased circulating PIGF was observed after treatment with everolimus in the RADIANT-III study (Hilfenhaus et al. 2013). PlGF levels reflect tumor aggressiveness (c) 2019 Society for Endocrinology Published by Bioscientifica Ltd. Printed in Great Britain 


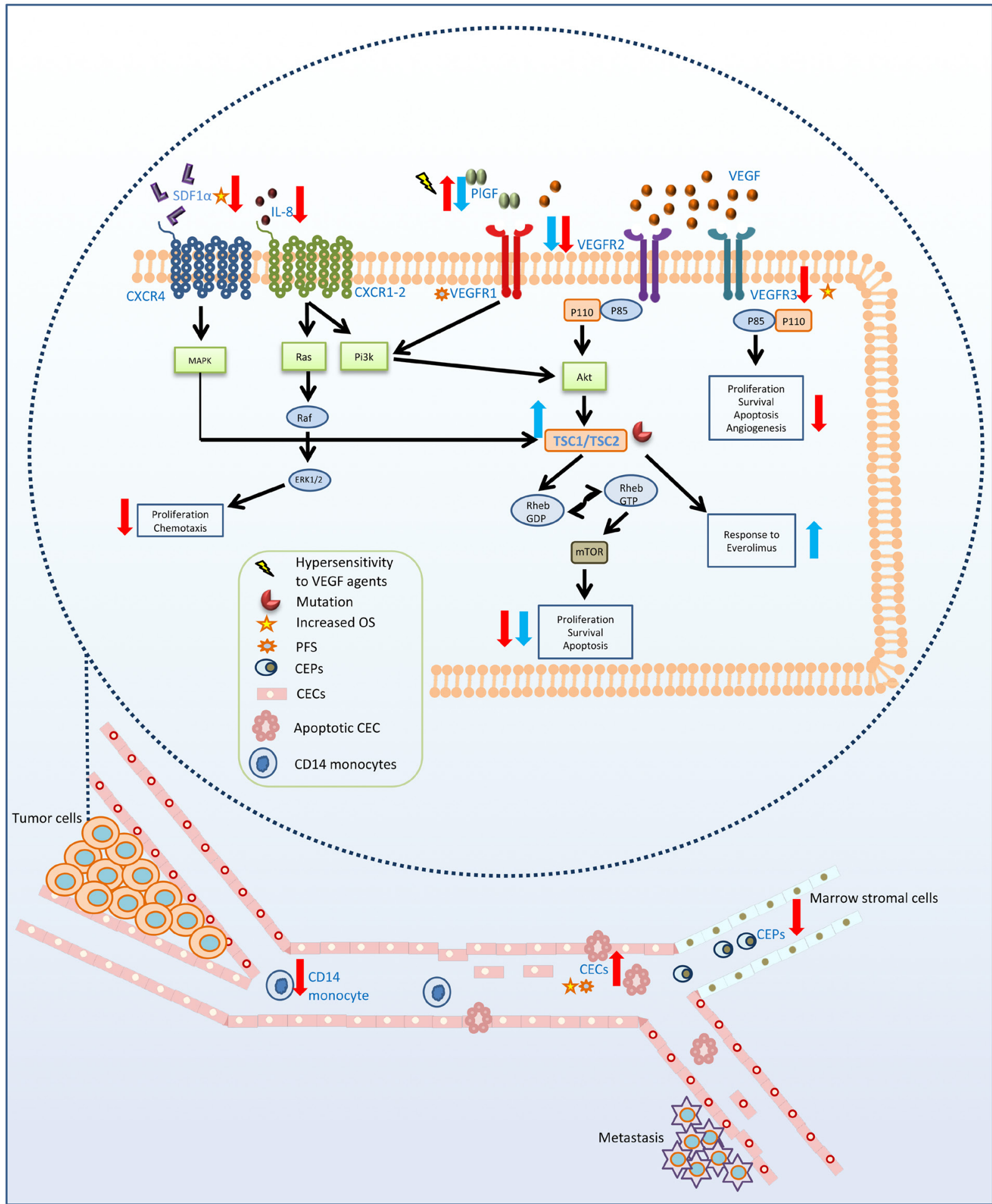

\section{Figure 5}

Therapeutic markers: molecular biomarkers for tyrosine kinase and mTOR inhibitors. Blue arrows represent the effect of the mTOR inhibitor everolimus and red arrows the effect of the tyrosine kinase inhibitor sunitinib. Molecular markers are presented in blue. Response to sunitinib has been related to decreased SDF1, IL-8, VEGFR 2-3, CD14 monocytes expressing VEGFR, decreased CEPs, increased CECs and probably decreased PIGF. Response to everolimus has been related to decreased PIGF and VEGFR2. Factors related to progression-free survival (PFS) and OS are also shown. CECS, circulating endothelial cells; CPECS, circulating endothelial precursors derived from the bone marrow; CXCR 1,2,4, chemokine family receptor 1,2,4; IL-8, interleukin-8; PIGF, placental growth factor; SDF-1 $\alpha$, stromal cell-derived factor $1 \alpha$; TSC 1-2, tuberous sclerosis complex 1-2; VEGF, vascular endothelial growth factor; VEGFR 1-3, vascular endothelial growth factor receptor 1-3. 
(Hilfenhaus et al. 2013), whereas others studies suggest that PIGF may also induce the formation of vascular networks that are hypersensitive to anti-VEGF therapy (Hedlund et al. 2013). Tumor-derived PlGF was postulated to become a potential predictive marker of anti-VEGF therapy (Hedlund et al. 2013).

As previously described for TKIs markers, midgut NENs and PNENs overexpress VEGF and its receptors (Christofori et al. 1995, Terris et al. 1998, La Rosa et al. 2003). In the RADIANT-III trial, a significantly progressive reduction in VEGFR-2 was observed after treatment with everolimus (Yao et al. 2012), but the specific clinical relevance and applicability in NENs must still be determined.

In addition, it has been suggested that mTOR-directed therapies may be more effective in tumors with tuberous sclerosis complex 1 (TSC1) somatic mutation, which acts as a regulator of mTOR pathway activation (Iyer et al. 2012). TSC is an autosomal dominant multisystem disorder caused by mutations of two tumor suppressor genes, TSC1 and TSC2, which encode for hamartin and tuberin, respectively. The interaction between these proteins is critical for cell growth and proliferation (Dworakowska \& Grossman 2009). Additionally, mutations in TSC2 have been described in PNENs with more aggressive features and progressive disease (Bombardieri et al. 2013). A schematic overview of current tumor biomarkers for mTOR inhibitors and TKIs is shown in Fig. 5.

\section{Biomarkers for immune therapy}

Programmed death-1 (PD-1) is expressed on T-, B- and myeloid cells and downregulates the activation of T-cells in tumors. The programmed death ligand 1 (PD-L1) and PD-1 are overexpressed in tumor-infiltrating lymphocytes in several types of cancer (Dong et al. 1999, Freeman et al. 2000, Lyford-Pike et al. 2013, He et al. 2015). PD-1 and PD-L1 induce lymphocyte apoptosis and cytokine secretion, which is crucial in tumor immunosuppression (Fan et al. 2016).

Initially, PD-L1 was described in SCLC (Schultheis et al. 2015), in lung typical-atypical carcinoids and in large cell neuroendocrine carcinoma (Tsuruoka et al. 2017). Subsequently, its presence was described and related with clinical features in other NENs; specifically, PDL-1 has been correlated with tumor stage and histological type in PNENs, as well as with worse survival (Fan et al. 2016). In GEP-NENs, PD-L1 has been related with more proliferative and aggressive tumors (Ghebeh et al. 2006, 2007, Sabatier et al. 2015, Kim et al. 2016), probably related to a higher immunogenicity in proliferative tumor cells (Kim et al. 2016). Despite PDL-1 and tumor grading being associated in GEP-NENs, no specific relation with the site of origin has been established (Kim et al. 2016). Some studies have reported an antitumor effect by drugs targeting PD-1 (nivolumab and pembrolizumab) and PD-L1 (MPDL3280A and BMS- 936559) (Ohaegbulam et al. 2015), especially in non-SCLC, which seems to be correlated to PD-L1 overexpression in the tumor (Powles et al. 2014). Unfortunately, the applicability in well-differentiated NENs seems to be limited, however. Further studies are required, especially focusing in the relation of PD-L1 expression and response rate in poorly differentiated NENs and carcinomas (Roberts et al. 2017).

\section{Conclusions and future directions}

The currently available biomarkers for NENs have important limitations, and there is an unmet need for accurate biomarkers that can be used for NEN diagnosis, prognosis and follow-up, therapy stratification and evaluation of treatment response. Currently, several prospective trials are evaluating the effect of novel therapeutic strategies in NENs ( ${ }^{90} \mathrm{Yt}$-labeled microspheres, lenvatinib, palbociclib, tremelimumab, bevacizumab, temozolomide, pasireotide, PDR001) and most trials include the evaluation of treatment-related follow-up markers. To date, these new biomarkers include peptides/ growth factors, DNA/RNA markers and CTCs.

Circulating markers, as well as, low-invasive techniques for early diagnosis (of disease and related complications) would be valuable to identify a personalized therapeutic sequence and follow-up. Circulating/tissue markers that could predict treatment response could assist to improve treatment-induced PFS. Finally, the combination of markers that enable to better predict the course of the disease, would also allow for better decision making with regard to the therapeutic strategy with the available different treatment options. In this respect, multianalyte measurement based on tumor genomics seems a promising tool for early outcome stratification and decision making. The development of blood-based analysis and liquid biopsy would represent non-invasive methods for diagnosis and prognosis as well. Additional validation studies will establish the definite role for this test. Other new parameters like cftDNA, miRNAs and CTCs and markers that predict response to TKIs and mTOR inhibitors need further investigation before clinical application is possible. Development and validation of novel biomarkers that improve diagnosis, assessment of tumor load, prediction of disease course, 
prognosis and outcome of intervention is still a challenge. In this context, genomics may represent the basis for developing multitranscript biomarkers, additionally, the combination of several markers (that provide multifaceted information), may offer better medical management and use of resources in order to improve diagnosis, treatment, quality of life and survival in NEN patients.

\section{Declaration of interest}

The authors declare that there is no conflict of interest that could be perceived as prejudicing the impartiality of this review.

\section{Funding}

This work did not receive any specific grant from any funding agency in the public, commercial or not-for-profit sector.

\section{References}

Angelescu R, Burada F, Angelescu C, Gheonea DI, Iordache S, Mixich F, Ioana M \& Saftoiu A 2013 Expression of vascular endothelial growth factor and epidermal growth factor receptor in pancreatic ductal adenocarcinomas, neuroendocrine tumours and chronic pancreatitis. Endoscopic Ultrasound 2 86-91. (https://doi.org/10.4103/23039027.117692)

Antonuzzo L, Meoni G \& Di Costanzo F 2013 Are circulating tumor cells a new, valid prognostic marker in neuroendocrine tumors? Journal of Clinical Oncology 31 2518. (https://doi.org/10.1200/ JCO.2013.49.2132)

Ardill JE \& O'Dorisio TM 2010 Circulating biomarkers in neuroendocrine tumors of the enteropancreatic tract: application to diagnosis, monitoring disease, and as prognostic indicators. Endocrinology and Metabolism Clinics of North America 39 777-790. (https://doi.org/10.1016/j.ecl.2010.09.001)

Arnold R, Wilke A, Rinke A, Mayer C, Kann PH, Klose KJ, Scherag A, Hahmann M, Muller HH \& Barth P 2008 Plasma chromogranin A as marker for survival in patients with metastatic endocrine gastroenteropancreatic tumors. Clinical Gastroenterology and Hepatology 6 820-827. (https://doi.org/10.1016/j.cgh.2008.02.052)

Aroldi F, Bertocchi P, Meriggi F, Abeni C, Ogliosi C, Rota L, Zambelli C, Bna C \& Zaniboni A 2014 Tyrosine kinase inhibitors in EGFRmutated large-cell neuroendocrine carcinoma of the lung? A case report. Case Reports in Oncology 7 478-483. (https://doi. org/10.1159/000365413)

Arvidsson Y, Bergstrom A, Arvidsson L, Kristiansson E, Ahlman H \& Nilsson O 2010 Hypoxia stimulates CXCR4 signalling in ileal carcinoids. Endocrine-Related Cancer 17 303-316. (https://doi. org/10.1677/ERC-09-0085)

Arvidsson Y, Rehammar A, Bergstrom A, Andersson E, Altiparmak G, Sward C, Wangberg B, Kristiansson E \& Nilsson O 2018 miRNA profiling of small intestinal neuroendocrine tumors defines novel molecular subtypes and identifies miR-375 as a biomarker of patient survival. Modern Pathology 31 1302-1317. (https://doi.org/10.1038/ s41379-018-0010-1)

Augeri DJ, Langenfeld E, Castle M, Gilleran JA \& Langenfeld J 2016 Inhibition of BMP and of TGFbeta receptors downregulates expression of XIAP and TAK1 leading to lung cancer cell death. Molecular Cancer 15 27. (https://doi.org/10.1186/s12943-016-0511-9)

Bajetta E, Ferrari L, Martinetti A, Celio L, Procopio G, Artale S, Zilembo N, Di Bartolomeo M, Seregni E \& Bombardieri E 1999
Chromogranin A, neuron specific enolase, carcinoembryonic antigen, and hydroxyindole acetic acid evaluation in patients with neuroendocrine tumors. Cancer 86 858-865. (https://doi. org/10.1002/(SICI)1097-0142(19990901)86:5<858::AIDCNCR23>3.0.CO;2-8)

Balkwill F 2004 Cancer and the chemokine network. Nature Reviews Cancer 4 540-550. (https://doi.org/10.1038/nrc1388)

Batterham RL, Le Roux CW, Cohen MA, Park AJ, Ellis SM, Patterson M, Frost GS, Ghatei MA \& Bloom SR 2003 Pancreatic polypeptide reduces appetite and food intake in humans. Journal of Clinical Endocrinology and Metabolism 88 3989-3992. (https://doi. org/10.1210/jc.2003-030630)

Baudin E, Gigliotti A, Ducreux M, Ropers J, Comoy E, Sabourin JC, Bidart JM, Cailleux AF, Bonacci R, Ruffie P, et al. 1998 Neuronspecific enolase and chromogranin A as markers of neuroendocrine tumours. British Journal of Cancer $\mathbf{7 8}$ 1102-1107. (https://doi. org/10.1038/bjc.1998.635)

Baudin E, Bidart JM, Bachelot A, Ducreux M, Elias D, Ruffie P \& Schlumberger M 2001 Impact of chromogranin A measurement in the work-up of neuroendocrine tumors. Annals of Oncology 12 (Supplement 2) S79-S82. (https://doi.org/10.1093/annonc/12. suppl_2.S79)

Beaudry P, Force J, Naumov GN, Wang A, Baker CH, Ryan A, Soker S, Johnson BE, Folkman J \& Heymach JV 2005 Differential effects of vascular endothelial growth factor receptor-2 inhibitor ZD6474 on circulating endothelial progenitors and mature circulating endothelial cells: implications for use as a surrogate marker of antiangiogenic activity. Clinical Cancer Research 11 3514-3522. (https://doi.org/10.1158/1078-0432.CCR-04-2271)

Bello CL, Deprimo SE, Friece C, Smeraglia J, Sherman L, Tye L, Baum C, Meropol NJ, Lenz H \& Kulke MH. 2006 Analysis of circulating biomarkers of sunitinib malate in patients with unresectable neuroendocrine tumors (NET): VEGF, IL-8, and soluble VEGF receptors 2 and 3. Journal of Clinical Oncology 24 (18 Supplement) abstract 4045 .

Benzerdjeb N, Berna P \& Sevestre H 2017 GLUT1: A novel tool reflecting proliferative activity of lung neuroendocrine tumors? Pathology International 67 32-36. (https://doi.org/10.1111/pin.12486)

Bergestuen DS, Gravning J, Haugaa KH, Sahakyan LG, Aakhus S, ThiisEvensen E, Oie E, Aukrust P, Attramadal H \& Edvardsen T 2010 Plasma CCN2/connective tissue growth factor is associated with right ventricular dysfunction in patients with neuroendocrine tumors. BMC Cancer 10 6. (https://doi.org/10.1186/1471-2407-10-6)

Bhattacharyya S, Toumpanakis C, Caplin ME \& Davar J 2008 Usefulness of N-terminal pro-brain natriuretic peptide as a biomarker of the presence of carcinoid heart disease. American Journal of Cardiology 102 938-942. (https://doi.org/10.1016/j.amjcard.2008.05.047)

Binderup T, Knigge UP, Federspiel B, Sommer P, Hasselby JP, Loft A \& Kjaer A 2013 Gene expression of glucose transporter 1 (GLUT1), hexokinase 1 and hexokinase 2 in gastroenteropancreatic neuroendocrine tumors: correlation with F-18-fluorodeoxyglucose positron emission tomography and cellular proliferation. Diagnostics 3 372-384. (https://doi.org/10.3390/diagnostics3040372)

Bison SM, Konijnenberg MW, Melis M, Pool SE, Bernsen MR, Teunissen JJM, Kwekkeboom DJ \& de Jong M 2014 Peptide receptor radionuclide therapy using radiolabeled somatostatin analogs: focus on future developments. Clinical and Translational Imaging 2 55-66. (https://doi.org/10.1007/s40336-014-0054-2)

Bodei L \& Weber WA 2018 Somatostatin receptor imaging of neuroendocrine tumors: From agonists to antagonists. Journal of Nuclear Medicine 59 907-908. (https://doi.org/10.2967/ jnumed.117.205161)

Bodei L, Kidd M, Modlin IM, Severi S, Drozdov I, Nicolini S, Kwekkeboom DJ, Krenning EP, Baum RP \& Paganelli G 2016 Measurement of circulating transcripts and gene cluster analysis predicts and defines therapeutic efficacy of peptide receptor (c) 2019 Society for Endocrinology Published by Bioscientifica Ltd. Printed in Great Britain 
radionuclide therapy (PRRT) in neuroendocrine tumors. European Journal of Nuclear Medicine and Molecular Imaging 43 839-851. (https://doi.org/10.1007/s00259-015-3250-z)

Bombardieri R, Moavero R, Roberto D, Cerminara C \& Curatolo P 2013 Pancreatic neuroendocrine tumor in a child with a tuberous sclerosis complex 2 (TSC2) mutation. Endocrine Practice 19 e124-e128. (https://doi.org/10.4158/EP13010.CR)

Boudreaux JP, Klimstra DS, Hassan MM, Woltering EA, Jensen RT, Goldsmith SJ, Nutting C, Bushnell DL, Caplin ME, Yao JC, et al. 2010 The NANETS consensus guideline for the diagnosis and management of neuroendocrine tumors: well-differentiated neuroendocrine tumors of the Jejunum, ileum, Appendix, and cecum. Pancreas 39 753-766. (https://doi.org/10.1097/ MPA.0b013e3181ebb2a5)

Brabander T, van der Zwan WA, Teunissen JJM, Kam BLR, de Herder WW, Feelders RA, Krenning EP \& Kwekkeboom DJ 2017 Pitfalls in the response evaluation after peptide receptor radionuclide therapy with $\left[{ }^{177} \mathrm{Lu}-\mathrm{DOTA}{ }^{0}, \mathrm{Tyr}^{3}\right]$ octreotate. Endocrine-Related Cancer 24 243-251. (https://doi.org/10.1530/ERC-16-0524)

Caplin ME, Pavel M \& Ruszniewski P 2014 Lanreotide in metastatic enteropancreatic neuroendocrine tumors. New England Journal of Medicine 371 1556-1557. (https://doi.org/10.1056/NEJMc1409757)

Capurso G, Festa S, Valente R, Piciucchi M, Panzuto F, Jensen RT \& Delle Fave G 2012 Molecular pathology and genetics of pancreatic endocrine tumours. Journal of Molecular Endocrinology 49 R37-R50. (https://doi.org/10.1530/JME-12-0069)

Carmeliet P, Moons L, Luttun A, Vincenti V, Compernolle V, De Mol M, Wu Y, Bono F, Devy L, Beck H, et al. 2001 Synergism between vascular endothelial growth factor and placental growth factor contributes to angiogenesis and plasma extravasation in pathological conditions. Nature Medicine 7 575-583. (https://doi. org/10.1038/87904)

Casado E, Garcia VM, Sanchez JJ, Gomez Del Pulgar MT, Feliu J, Maurel J, Castelo B, Moreno Rubio J, Lopez RAB, Garcia-Cabezas MÁ, et al. 2012 Upregulation of trefoil factor 3 (TFF3) after rectal cancer chemoradiotherapy is an adverse prognostic factor and a potential therapeutic target. International Journal of Radiation Oncology, Biology, Physics 84 1151-1158. (https://doi.org/10.1016/j.ijrobp.2012.01.083)

Christmann M, Verbeek B, Roos WP \& Kaina B 2011 O(6)Methylguanine-DNA methyltransferase (MGMT) in normal tissues and tumors: enzyme activity, promoter methylation and immunohistochemistry. Biochimica and Biophysica Acta 1816 179-190. (https://doi.org/10.1016/j.bbcan.2011.06.002)

Christofori G, Naik P \& Hanahan D 1995 Vascular endothelial growth factor and its receptors, flt- 1 and flk- 1 , are expressed in normal pancreatic islets and throughout islet cell tumorigenesis. Molecular Endocrinology 9 1760-1770. (https://doi.org/10.1210/ mend.9.12.8614412)

Cimitan M, Buonadonna A, Cannizzaro R, Canzonieri V, Borsatti E, Ruffo R \& De Apollonia L 2003 Somatostatin receptor scintigraphy versus chromogranin A assay in the management of patients with neuroendocrine tumors of different types: clinical role. Annals of Oncology 14 1135-1141. (https://doi.org/10.1093/annonc/mdg279)

Cingarlini S, Bonomi M, Corbo V, Scarpa A \& Tortora G 2012 Profiling mTOR pathway in neuroendocrine tumors. Targeted Oncology $\mathbf{7}$ 183-188. (https://doi.org/10.1007/s11523-012-0226-9)

Clavo AC, Brown RS \& Wahl RL 1995 Fluorodeoxyglucose uptake in human cancer cell lines is increased by hypoxia. Journal of Nuclear Medicine 36 1625-1632.

Clift AK, Faiz O, Goldin R, Martin J, Wasan H, Liedke MO, Schloericke E, Malczewska A, Rindi G, Kidd M, et al. 2017 Predicting the survival of patients with small bowel neuroendocrine tumours: comparison of 3 systems. Endocrine Connections 6 71-81. (https://doi. org/10.1530/EC-16-0114)

Cohen SJ, Punt CJ, Iannotti N, Saidman BH, Sabbath KD, Gabrail NY, Picus J, Morse M, Mitchell E, Miller MC, et al. 2008 Relationship of circulating tumor cells to tumor response, progression-free survival, and overall survival in patients with metastatic colorectal cancer. Journal of Clinical Oncology 26 3213-3221. (https://doi.org/10.1200/ JCO.2007.15.8923)

Condeelis J \& Pollard JW 2006 Macrophages: obligate partners for tumor cell migration, invasion, and metastasis. Cell 124 263-266. (https:// doi.org/10.1016/j.cell.2006.01.007)

Costanzo R, Montanino A, Di Maio M, Piccirillo MC, Sandomenico C, Giordano P, Daniele G, Franco R, Perrone F, Rocco G, et al. 2013 Advanced non-small-cell lung cancer with epidermal growth factor receptor mutations: current evidence and future perspectives. Expert Review of Anticancer Therapy 13 1207-1218. (https://doi.org/10.1586/ 14737140.2013.845092)

Cristofanilli M, Hayes DF, Budd GT, Ellis MJ, Stopeck A, Reuben JM, Doyle GV, Matera J, Allard WJ, Miller MC, et al. 2005 Circulating tumor cells: a novel prognostic factor for newly diagnosed metastatic breast cancer. Journal of Clinical Oncology 23 1420-1430. (https://doi. org/10.1200/JCO.2005.08.140)

Cui T, Hurtig M, Elgue G, Li SC, Veronesi G, Essaghir A, Demoulin JB, Pelosi G, Alimohammadi M, Oberg K, et al. 2010 Paraneoplastic antigen Ma2 autoantibodies as specific blood biomarkers for detection of early recurrence of small intestine neuroendocrine tumors. PLoS One 5 e16010. (https://doi.org/10.1371/journal.pone.0016010)

Cwikla JB, Bodei L, Kolasinska-Cwikla A, Sankowski A, Modlin IM \& Kidd M 2015 Circulating transcript analysis (NETest) in GEP-NETs treated With somatostatin analogs defines therapy. Journal of Clinical Endocrinology and Metabolism 100 E1437-E1445.

D’Amico MA, Ghinassi B, Izzicupo P, Manzoli L \& Di Baldassarre A 2014 Biological function and clinical relevance of chromogranin A and derived peptides. Endocrine Connections 3 R45-R54. (https://doi. org/10.1530/EC-14-0027)

Dasari A, Shen C, Halperin D, Zhao B, Zhou S, Xu Y, Shih T \& Yao JC 2017 Trends in the incidence, prevalence, and survival outcomes in patients with neuroendocrine tumors in the United States. JAMA Oncology 3 1335-1342. (https://doi.org/10.1001/ jamaoncol.2017.0589)

de Herder WW, Kwekkeboom DJ, Feelders RA, van Aken MO, Lamberts SWJ, van der Lely AJ \& Krenning EP 2006 Somatostatin receptor imaging for neuroendocrine tumors. Pituitary 9 243-248. (https://doi.org/10.1007/s11102-006-0270-5)

Delbaldo C, Faivre S, Dreyer C \& Raymond E 2012 Sunitinib in advanced pancreatic neuroendocrine tumors: latest evidence and clinical potential. Therapeutic Advances in Medical Oncology 4 9-18. (https://doi.org/10.1177/1758834011428147)

Demes M, Aszyk C, Bartsch H, Schirren J \& Fisseler-Eckhoff A 2016 Differential miRNA-expression as an adjunctive diagnostic tool in neuroendocrine tumors of the lung. Cancers 8 38. (https://doi. org/10.3390/cancers8040038)

Deprimo SE, Bello CL, Smeraglia J, Baum CM, Spinella D, Rini BI, Michaelson MD \& Motzer RJ 2007 Circulating protein biomarkers of pharmacodynamic activity of sunitinib in patients with metastatic renal cell carcinoma: modulation of VEGF and VEGF-related proteins. Journal of Translational Medicine 5 32. (https://doi. org/10.1186/1479-5876-5-32)

Di Leva G \& Croce CM 2013 miRNA profiling of cancer. Current Opinion in Genetics and Development 23 3-11. (https://doi.org/10.1016/j. gde.2013.01.004)

Diaz LA, Jr \& Bardelli A 2014 Liquid biopsies: genotyping circulating tumor DNA. Journal of Clinical Oncology 32 579-586. (https://doi. org/10.1200/JCO.2012.45.2011)

Dogeas E, Karagkounis G, Heaphy CM, Hirose K, Pawlik TM, Wolfgang CL, Meeker A, Hruban RH, Cameron JL \& Choti MA 2014 Alternative lengthening of telomeres predicts site of origin in neuroendocrine tumor liver metastases. Journal of the American College of Surgeons 218 628-635. (https://doi.org/10.1016/j. jamcollsurg.2014.01.001) https://erc.bioscientifica.com

https://doi.org/10.1530/ERC-18-0354 (c) 2019 Society for Endocrinology Published by Bioscientifica Ltd. Printed in Great Britain 
Dong H, Zhu G, Tamada K \& Chen L 1999 b7-h1 B7-H1, A third member of the B7 family, co-stimulates T-cell proliferation and interleukin-10 secretion. Nature Medicine 5 1365-1369. (https://doi. org/10.1038/70932)

Duque M, Modlin IM, Gupta A \& Saif MW 2013 Biomarkers in neuroendocrine tumors. Journal of the Pancreas 14 372-376. (https:// doi.org/10.6092/1590-8577/1692)

Dworakowska D \& Grossman AB 2009 Are neuroendocrine tumours a feature of tuberous sclerosis? A systematic review. Endocrine-Related Cancer 16 45-58. (https://doi.org/10.1677/ERC-08-0142)

Edfeldt K, Daskalakis K, Backlin C, Norlen O, Tiensuu Janson E, Westin G, Hellman P \& Stalberg P 2017 DcR3, TFF3 and midkine are novel serum biomarkers in small intestinal neuroendocrine tumors. Neuroendocrinology 105 170-181. (https://doi. org/10.1159/000452891)

Eskeland NL, Zhou A, Dinh TQ, Wu H, Parmer RJ, Mains RE \& O'Connor DT 1996 Chromogranin A processing and secretion: specific role of endogenous and exogenous prohormone convertases in the regulated secretory pathway. Journal of Clinical Investigation $\mathbf{9 8}$ 148-156. (https://doi.org/10.1172/JCI118760)

Fan Y, Ma K, Wang C, Ning J, Hu Y, Dong D, Dong X, Geng Q, Li E \& Wu Y 2016 Prognostic value of PD-L1 and PD-1 expression in pulmonary neuroendocrine tumors. OncoTargets and Therapy 9 6075-6082. (https://doi.org/10.2147/OTT.S115054)

Fernandez Pujol B, Lucibello FC, Gehling UM, Lindemann K, Weidner N, Zuzarte ML, Adamkiewicz J, Elsasser HP, Muller R \& Havemann K 2000 Endothelial-like cells derived from human CD14 positive monocytes. Differentiation 65 287-300. (https://doi. org/10.1046/j.1432-0436.2000.6550287.x)

Ferrari L, Seregni E, Lucignani G, Bajetta E, Martinetti A, Aliberti G, Pallotti F, Procopio G, Della Torre S, Luksch R, et al. 2004 Accuracy and clinical correlates of two different methods for chromogranin A assay in neuroendocrine tumors. International Journal of Biological Markers 19 295-304.

Fischer C, Mazzone M, Jonckx B \& Carmeliet P 2008 FLT1 and its ligands VEGFB and PlGF: drug targets for anti-angiogenic therapy? Nature Reviews Cancer 8 942-956. (https://doi.org/10.1038/nrc2524)

Fotouhi O, Kjellin H, Larsson C, Hashemi J, Barriuso J, Juhlin CC, Lu M, Hoog A, Pastrian LG, Lamarca A, et al. 2016 Proteomics suggests a role for APC-survivin in response to somatostatin analog treatment of neuroendocrine tumors. Journal of Clinical Endocrinology and Metabolism 101 3616-3627. (https://doi.org/10.1210/jc.2016-2028)

Francis G \& Stein S 2015 Circulating cell-free tumour DNA in the management of cancer. International Journal of Molecular Sciences 16 14122-14142. (https://doi.org/10.3390/ijms160614122)

Francis JM, Kiezun A, Ramos AH, Serra S, Pedamallu CS, Qian ZR, Banck MS, Kanwar R, Kulkarni AA, Karpathakis A, et al. 2013 Somatic mutation of CDKN1B in small intestine neuroendocrine tumors. Nature Genetics 45 1483-1486. (https://doi.org/10.1038/ ng.2821)

Frederiksen CM, Knudsen S, Laurberg S \& Orntoft TF 2003 Classification of Dukes' B and C colorectal cancers using expression arrays. Journal of Cancer Research and Clinical Oncology 129 263-271. (https://doi. org/10.1007/s00432-003-0434-x)

Freeman GJ, Long AJ, Iwai Y, Bourque K, Chernova T, Nishimura H, Fitz LJ, Malenkovich N, Okazaki T, Byrne MC, et al. 2000 Engagement of the PD-1 immunoinhibitory receptor by a novel B7 family member leads to negative regulation of lymphocyte activation. Journal of Experimental Medicine 192 1027-1034. (https:// doi.org/10.1084/jem.192.7.1027)

Fujino M, Aishima S, Shindo K, Oda Y, Morimatsu K, Tsutsumi K, Otsuka T, Tanaka M \& Oda Y 2016 Expression of glucose transporter-1 is correlated with hypoxia-inducible factor 1alpha and malignant potential in pancreatic neuroendocrine tumors. Oncology Letters 12 3337-3343. (https://doi.org/10.3892/ol.2016.5092)
Gao Y, Gao H, Wang G, Yin L, Xu W, Peng Y, Wu J, Jiang K \& Miao Y 2018 A meta-analysis of prognostic factor of pancreatic neuroendocrine neoplasms. Scientific Reports 8 7271. (https://doi. org/10.1038/s41598-018-24072-0)

Gerson SL 2002 Clinical relevance of MGMT in the treatment of cancer. Journal of Clinical Oncology 20 2388-2399. (https://doi.org/10.1200/ JCO.2002.06.110)

Ghebeh H, Mohammed S, Al-Omair A, Qattan A, Lehe C, Al-Qudaihi G, Elkum N, Alshabanah M, Bin Amer S, Tulbah A, et al. 2006 The B7-H1 (PD-L1) T lymphocyte-inhibitory molecule is expressed in breast cancer patients with infiltrating ductal carcinoma: correlation with important high-risk prognostic factors. Neoplasia 8 190-198. (https://doi.org/10.1593/neo.05733)

Ghebeh H, Tulbah A, Mohammed S, Elkum N, Bin Amer SM, Al-Tweigeri T \& Dermime S 2007 Expression of B7-H1 in breast cancer patients is strongly associated with high proliferative Ki-67expressing tumor cells. International Journal of Cancer 121 751-758. (https://doi.org/10.1002/ijc.22703)

Gilbert JA, Adhikari LJ, Lloyd RV, Rubin J, Haluska P, Carboni JM, Gottardis MM \& Ames MM 2010 Molecular markers for novel therapies in neuroendocrine (carcinoid) tumors. Endocrine-Related Cancer 17 623-636. (https://doi.org/10.1677/ERC-09-0318)

Grabowski P, Griss S, Arnold CN, Horsch D, Goke R, Arnold R, Heine B, Stein H, Zeitz M \& Scherubl H 2005 Nuclear survivin is a powerful novel prognostic marker in gastroenteropancreatic neuroendocrine tumor disease. Neuroendocrinology 81 1-9. (https://doi. org/10.1159/000084892)

Grouzmann E, Gicquel C, Plouin PF, Schlumberger M, Comoy E \& Bohuon C 1990 Neuropeptide Y and neuron-specific enolase levels in benign and malignant pheochromocytomas. Cancer 66 1833-1835. (https://doi.org/10.1002/10970142(19901015)66:8<1833::AID-CNCR2820660831>3.0.CO;2-9)

Gut P, Czarnywojtek A, Fischbach J, Baczyk M, Ziemnicka K, Wrotkowska E, Gryczynska M \& Ruchala M 2016 Chromogranin A - unspecific neuroendocrine marker. Clinical utility and potential diagnostic pitfalls. Archives of Medical Science 12 1-9. (https://doi. org/10.5114/aoms.2016.57577)

He J, Hu Y, Hu M \& Li B 2015 Development of PD-1/PD-L1 pathway in tumor immune microenvironment and treatment for non-small cell lung cancer. Scientific Reports 5 13110. (https://doi.org/10.1038/ srep13110)

Heaphy CM, de Wilde RF, Jiao Y, Klein AP, Edil BH, Shi C, Bettegowda C, Rodriguez FJ, Eberhart CG, Hebbar S, et al. 2011 Altered telomeres in tumors with ATRX and DAXX mutations. Science 333 425. (https:// doi.org/10.1126/science.1207313)

Hedlund EM, Yang X, Zhang Y, Yang Y, Shibuya M, Zhong W, Sun B, Liu Y, Hosaka K \& Cao Y 2013 Tumor cell-derived placental growth factor sensitizes antiangiogenic and antitumor effects of anti-VEGF drugs. PNAS 110 654-659.

Herrera-Martinez AD, Gahete MD, Sanchez-Sanchez R, Salas RO, SerranoBlanch R, Salvatierra Á, Hofland LJ, Luque RM, Galvez-Moreno MA \& Castano JP 2017 The components of somatostatin and ghrelin systems are altered in neuroendocrine lung carcinoids and associated to clinical-histological features. Lung Cancer 109 128-136. (https:// doi.org/10.1016/j.lungcan.2017.05.006)

Herrera-Martinez AD, Gahete MD, Pedraza-Arevalo S, SanchezSanchez R, Ortega-Salas R, Serrano-Blanch R, Luque RM, GalvezMoreno MA \& Castano JP 2018 Clinical and functional implication of the components of somatostatin system in gastroenteropancreatic neuroendocrine tumors. Endocrine 59 426-437. (https://doi. org/10.1007/s12020-017-1482-3)

Hess KR, Anderson K, Symmans WF, Valero V, Ibrahim N, Mejia JA, Booser D, Theriault RL, Buzdar AU, Dempsey PJ, et al. 2006 Pharmacogenomic predictor of sensitivity to preoperative chemotherapy with paclitaxel and fluorouracil, doxorubicin, and c) 2019 Society for Endocrinology Published by Bioscientifica Ltd. Printed in Great Britain 
cyclophosphamide in breast cancer. Journal of Clinical Oncology $\mathbf{2 4}$ 4236-4244. (https://doi.org/10.1200/JCO.2006.05.6861)

Hilfenhaus G, Gohrig A, Pape UF, Neumann T, Jann H, Zdunek D, Hess G, Stassen JM, Wiedenmann B, Detjen K, et al. 2013 Placental growth factor supports neuroendocrine tumor growth and predicts disease prognosis in patients. Endocrine-Related Cancer 20 305-319. (https://doi.org/10.1530/ERC-12-0223)

Hofland J, Feelders RA, Brabander T, Franssen GJH \& de Herder WW 2018 Recent developments in the diagnosis and therapy of welldifferentiated neuroendocrine tumours. Netherlands Journal of Medicine 76 100-108.

Holbourn KP, Acharya KR \& Perbal B 2008 The CCN family of proteins: structure-function relationships. Trends in Biochemical Sciences $\mathbf{3 3}$ 461-473. (https://doi.org/10.1016/j.tibs.2008.07.006)

Hope TA, Bergsland EK, Bozkurt MF, Graham M, Heaney AP, Herrmann K, Howe JR, Kulke MH, Kunz PL, Mailman J, et al. 2018 Appropriate use criteria for somatostatin receptor PET imaging in neuroendocrine tumors. Journal of Nuclear Medicine 59 66-74. (https://doi.org/10.2967/jnumed.117.202275)

Hu R, Yan Y, Li Q, Lin Y, Jin W, Li H, Lu Y \& Pang T 2010 Increased drug efflux along with midkine gene high expression in childhood B-lineage acute lymphoblastic leukemia cells. International Journal of Hematology 92 105-110. (https://doi.org/10.1007/s12185-010-0613-x)

Huang D, Ding Y, Zhou M, Rini BI, Petillo D, Qian CN, Kahnoski R, Futreal PA, Furge KA \& Teh BT 2010 Interleukin-8 mediates resistance to antiangiogenic agent sunitinib in renal cell carcinoma. Cancer Research 70 1063-1071. (https://doi.org/10.1158/0008-5472. CAN-09-3965)

Huang YG, Li YF, Wang LP \& Zhang Y 2013 Aberrant expression of trefoil factor 3 is associated with colorectal carcinoma metastasis. Journal of Cancer Research and Therapeutics 9 376-380. (https://doi. org/10.4103/0973-1482.119308)

Hussain F, Wang J, Ahmed R, Guest SK, Lam EW, Stamp G \& El-Bahrawy M 2010 The expression of IL-8 and IL-8 receptors in pancreatic adenocarcinomas and pancreatic neuroendocrine tumours. Cytokine 49 134-140. (https://doi.org/10.1016/j. cyto.2009.11.010)

Isgro MA, Bottoni P \& Scatena R 2015 Neuron-specific enolase as a biomarker: biochemical and clinical aspects. Advances in Experimental Medicine and Biology 867 125-143. (https://doi.org/10.1007/978-94017-7215-0_9)

Iyer G, Hanrahan AJ, Milowsky MI, Al-Ahmadie H, Scott SN, Janakiraman M, Pirun M, Sander C, Socci ND, Ostrovnaya I, et al. 2012 Genome sequencing identifies a basis for everolimus sensitivity. Science 338 221. (https://doi.org/10.1126/science.1226344)

Janson ET, Holmberg L, Stridsberg M, Eriksson B, Theodorsson E, Wilander E \& Oberg K 1997 Carcinoid tumors: analysis of prognostic factors and survival in 301 patients from a referral center. Annals of Oncology 8 685-690. (https://doi.org/10.1023/A:1008215730767)

Jiao Y, Shi C, Edil BH, de Wilde RF, Klimstra DS, Maitra A, Schulick RD, Tang LH, Wolfgang CL, Choti MA, et al. 2011 DAXX/ATRX, MEN1, and mTOR pathway genes are frequently altered in pancreatic neuroendocrine tumors. Science 331 1199-1203. (https://doi. org/10.1126/science.1200609)

Jin CD, Kim MH, Guo LZ, Li SH \& Han J 2015 Falsely high B-type natriuretic peptide concentration in patients without heart failure attributed to AxSYM assay: case series of eight subjects. ESC Heart Failure 2 37-39. (https://doi.org/10.1002/ehf2.12024)

Jones DR 2014 Measuring midkine: the utility of midkine as a biomarker in cancer and other diseases. British Journal of Pharmacology 171 2925-2939. (https://doi.org/10.1111/bph.12601)

Jorgensen LG, Lober J, Carlsen NL, Momsen G \& Hirsch FR 1996 Serum neuron specific enolase (S-NSE) reference interval evaluation by time-resolved immunofluorometry compared with a radioimmunoassay. Clinica Chimica Acta 249 77-91.
Kaemmerer D, Reimann C, Specht E, Wirtz RM, Sayeg M, Baum RP, Schulz S \& Lupp A 2015 Differential expression and prognostic value of the chemokine receptor CXCR4 in bronchopulmonary neuroendocrine neoplasms. Oncotarget 6 3346-3358. (https://doi. org/10.18632/oncotarget.3242)

Kalka C, Masuda H, Takahashi T, Gordon R, Tepper O, Gravereaux E, Pieczek A, Iwaguro H, Hayashi SI, Isner JM, et al. 2000 Vascular endothelial growth factor(165) gene transfer augments circulating endothelial progenitor cells in human subjects. Circulation Research 86 1198-1202. (https://doi.org/10.1161/01.RES.86.12.1198)

Kalkner KM, Janson ET, Nilsson S, Carlsson S, Oberg K \& Westlin JE 1995 Somatostatin receptor scintigraphy in patients with carcinoid tumors: comparison between radioligand uptake and tumor markers. Cancer Research 55 5801s-5804s.

Kanakis G, Grimelius L, Spathis A, Tringidou R, Rassidakis GZ, Oberg K, Kaltsas G \& Tsolakis AV 2015 Expression of somatostatin Receptors 1-5 and dopamine Receptor 2 in lung carcinoids: implications for a therapeutic role. Neuroendocrinology 101 211-222. (https://doi. org $/ 10.1159 / 000381061)$

Khan MS, Tsigani T, Rashid M, Rabouhans JS, Yu D, Luong TV, Caplin M \& Meyer T 2011 Circulating tumor cells and EpCAM expression in neuroendocrine tumors. Clinical Cancer Research 17 337-345. (https://doi.org/10.1158/1078-0432.CCR-10-1776)

Khan MS, Kirkwood A, Tsigani T, Garcia-Hernandez J, Hartley JA, Caplin ME \& Meyer T 2013 Circulating tumor cells as prognostic markers in neuroendocrine tumors. Journal of Clinical Oncology 31 365-372. (https://doi.org/10.1200/JCO.2012.44.2905)

Kidd M, Drozdov I \& Modlin I 2015 Blood and tissue neuroendocrine tumor gene cluster analysis correlate, define hallmarks and predict disease status. Endocrine-Related Cancer 22 561-575. (https://doi. org/10.1530/ERC-15-0092)

Kim ST, Ha SY, Lee S, Ahn S, Lee J, Park SH, Park JO, Lim HY, Kang WK, Kim KM, et al. 2016 The impact of PD-L1 expression in patients with metastatic GEP-NETs. Journal of Cancer 7 484-489. (https://doi. org/10.7150/jca.13711)

Kim JY, Brosnan-Cashman JA, An S, Kim SJ, Song KB, Kim MS, Kim MJ, Hwang DW, Meeker AK, Yu E, et al. 2017 Alternative lengthening of telomeres in primary pancreatic neuroendocrine neoplasms is associated with aggressive clinical behavior and poor survival. Clinical Cancer Research 23 1598-1606.

Korner M, Waser B, Schonbrunn A, Perren A \& Reubi JC 2012 Somatostatin receptor subtype $2 \mathrm{~A}$ immunohistochemistry using a new monoclonal antibody selects tumors suitable for in vivo somatostatin receptor targeting. American Journal of Surgical Pathology 36 242-252. (https://doi.org/10.1097/PAS.0b013e31823d07f3)

Korse CM, Bonfrer JM, Aaronson NK, Hart AA \& Taal BG 2009a Chromogranin A as an alternative to 5-hydroxyindoleacetic acid in the evaluation of symptoms during treatment of patients with neuroendocrine tumors. Neuroendocrinology 89 296-301. (https://doi. org/10.1159/000162876)

Korse CM, Taal BG, de Groot CA, Bakker RH \& Bonfrer JM 2009b Chromogranin-A and N-terminal pro-brain natriuretic peptide: an excellent pair of biomarkers for diagnostics in patients with neuroendocrine tumor. Journal of Clinical Oncology 27 4293-4299. (https://doi.org/10.1200/JCO.2008.18.7047)

Korse CM, Taal BG, Bonfrer JM, Vincent A, van Velthuysen ML \& Baas P 2011 An elevated progastrin-releasing peptide level in patients with well-differentiated neuroendocrine tumours indicates a primary tumour in the lung and predicts a shorter survival. Annals of Oncology 22 2625-2630. (https://doi.org/10.1093/annonc/mdr007)

Korse CM, Holdenrieder S, Zhi XY, Zhang X, Qiu L, Geistanger A, Lisy MR, Wehnl B, van den Broek D, Escudero JM, et al. 2015 Multicenter evaluation of a new progastrin-releasing peptide (ProGRP) immunoassay across Europe and China. Clinica Chimica Acta 438 388-395. (https://doi.org/10.1016/j.cca.2014.09.015) (c) 2019 Society for Endocrinology Published by Bioscientifica Ltd. Printed in Great Britain 
Kulke MH, Hornick JL, Frauenhoffer C, Hooshmand S, Ryan DP, Enzinger PC, Meyerhardt JA, Clark JW, Stuart K, Fuchs CS, et al. 2009 O6-Methylguanine DNA methyltransferase deficiency and response to temozolomide-based therapy in patients with neuroendocrine tumors. Clinical Cancer Research 15 338-345. (https://doi.org/10.1158/1078-0432.CCR-08-1476)

Kulke MH, Anthony LB, Bushnell DL, de Herder WW, Goldsmith SJ, Klimstra DS, Marx SJ, Pasieka JL, Pommier RF, Yao JC, et al. 2010 NANETS treatment guidelines: well-differentiated neuroendocrine tumors of the stomach and pancreas. Pancreas 39 735-752.

Kulke MH, Shah MH, Benson AB, 3rd, Bergsland E, Berlin JD, Blaszkowsky LS, Emerson L, Engstrom PF, Fanta P, Giordano T, et al. 2015 Neuroendocrine tumors, version 1.2015. Journal of the National Comprehensive Cancer Network 13 78-108.

Kunikowska J, Lewington V \& Krolicki L 2017 Optimizing somatostatin receptor imaging in patients With neuroendocrine tumors: the impact of 99mTc-HYNICTOC SPECT/SPECT/CT versus 68Ga-DOTATATE PET/CT upon clinical management. Clinical Nuclear Medicine 42 905-911. (https://doi.org/10.1097/ RLU.0000000000001877)

Kwekkeboom DJ, Kam BL, van Essen M, Teunissen JJ, van Eijck CH, Valkema R, de Jong M, de Herder WW \& Krenning EP 2010 Somatostatin-receptor-based imaging and therapy of gastroenteropancreatic neuroendocrine tumors. Endocrine-Related Cancer 17 R53-R73. (https://doi.org/10.1677/ERC-09-0078)

La Rosa S, Uccella S, Finzi G, Albarello L, Sessa F \& Capella C 2003 Localization of vascular endothelial growth factor and its receptors in digestive endocrine tumors: correlation with microvessel density and clinicopathologic features. Human Pathology 34 18-27. (https:// doi.org/10.1053/hupa.2003.56)

Lambertini C, Barzaghi-Rinaudo P, D'Amato L, Schulz S, Nuciforo P \& Schmid HA 2013 Evaluation of somatostatin receptor subtype expression in human neuroendocrine tumors using two sets of new monoclonal antibodies. Regulatory Peptides 187 35-41. (https://doi. org/10.1016/j.regpep.2013.10.007)

Landry CS, Cavaness K, Celinski S \& Preskitt J 2014 Biochemical prognostic indicators for pancreatic neuroendocrine tumors and small bowel neuroendocrine tumors. Gland Surgery 3 215-218. (https://doi.org/10.3978/j.issn.2227-684X.2014.10.01)

Li J, Luo G, Fu D, Jin C, Hao S, Yang F, Wang X, Yao L \& Ni Q 2011 Preoperative diagnosis of nonfunctioning pancreatic neuroendocrine tumors. Medical Oncology 28 1027-1031. (https://doi.org/10.1007/ s12032-010-9611-3)

Li SC, Essaghir A, Martijn C, Lloyd RV, Demoulin JB, Oberg K \& Giandomenico V 2013 Global microRNA profiling of welldifferentiated small intestinal neuroendocrine tumors. Modern Pathology 26 685-696. (https://doi.org/10.1038/modpathol.2012.216)

Lin WW \& Hsieh SL 2011 Decoy receptor 3: a pleiotropic immunomodulator and biomarker for inflammatory diseases, autoimmune diseases and cancer. Biochemical Pharmacology $\mathbf{8 1}$ 838-847. (https://doi.org/10.1016/j.bcp.2011.01.011)

Liu L \& Gerson SL 2006 Targeted modulation of MGMT: clinical implications. Clinical Cancer Research 12 328-331. (https://doi. org/10.1158/1078-0432.CCR-05-2543)

Liu B, Tang LH, Liu Z, Mei M, Yu R, Dhall D, Qiao XW, Zhang TP, Zhao YP, Liu TH, et al. 2014 Alpha-internexin: a novel biomarker for pancreatic neuroendocrine tumor aggressiveness. Journal of Clinical Endocrinology and Metabolism 99 E786-E795. (https://doi. org/10.1210/jc.2013-2874)

Lyford-Pike S, Peng S, Young GD, Taube JM, Westra WH, Akpeng B, Bruno TC, Richmon JD, Wang H, Bishop JA, et al. 2013 Evidence for a role of the PD-1:PD-L1 pathway in immune resistance of HPVassociated head and neck squamous cell carcinoma. Cancer Research 73 1733-1741. (https://doi.org/10.1158/0008-5472.CAN-12-2384)

Mafficini A \& Scarpa A 2018 Genomic landscape of pancreatic neuroendocrine tumours: the International Cancer Genome
Consortium. Journal of Endocrinology 236 R161-R167. (https://doi. org/10.1530/JOE-17-0560)

Marinoni I, Kurrer AS, Vassella E, Dettmer M, Rudolph T, Banz V, Hunger F, Pasquinelli S, Speel EJ \& Perren A 2014 Loss of DAXX and ATRX are associated with chromosome instability and reduced survival of patients with pancreatic neuroendocrine tumors. Gastroenterology 146 453.e455-460.e455. (https://doi.org/10.1053/j. gastro.2013.10.020)

Marotta V, Zatelli MC, Sciammarella C, Ambrosio MR, Bondanelli M, Colao A \& Faggiano A 2018 Chromogranin A as circulating marker for diagnosis and management of neuroendocrine neoplasms: more flaws than fame. Endocrine-Related Cancer 25 R11-R29. (https://doi. org/10.1530/ERC-17-0269)

Marzese DM, Hirose H \& Hoon DS 2013 Diagnostic and prognostic value of circulating tumor-related DNA in cancer patients. Expert Review of Molecular Diagnostics 13 827-844. (https://doi.org/10.1586/ 14737159.2013.845088)

Mateo J, Heymach JV \& Zurita AJ 2012 Circulating biomarkers of response to sunitinib in gastroenteropancreatic neuroendocrine tumors: current data and clinical outlook. Molecular Diagnosis and Therapy 16 151-161. (https://doi.org/10.2165/11632590-00000000000000)

McDonald TJ, Jornvall H, Nilsson G, Vagne M, Ghatei M, Bloom SR \& Mutt V 1979 Characterization of a gastrin releasing peptide from porcine non-antral gastric tissue. Biochemical and Biophysical Research Communications 90 227-233. (https://doi.org/10.1016/0006291X(79)91614-0)

Metz DC \& Jensen RT 2008 Gastrointestinal neuroendocrine tumors: pancreatic endocrine tumors. Gastroenterology 135 1469-1492. (https://doi.org/10.1053/j.gastro.2008.05.047)

Mihaly SR, Ninomiya-Tsuji J \& Morioka S 2014 TAK1 control of cell death. Cell Death and Differentiation 21 1667-1676. (https://doi. $\operatorname{org} / 10.1038 /$ cdd.2014.123)

Miller HC, Frampton AE, Malczewska A, Ottaviani S, Stronach EA, Flora R, Kaemmerer D, Schwach G, Pfragner R, Faiz O, et al. 2016 MicroRNAs associated with small bowel neuroendocrine tumours and their metastases. Endocrine-Related Cancer 23 711-726. (https:// doi.org/10.1530/ERC-16-0044)

Mizutani G, Nakanishi Y, Watanabe N, Honma T, Obana Y, Seki T, Ohni S \& Nemoto N 2012 Expression of somatostatin receptor (sstr) subtypes (SSTR-1, 2A, 3, 4 and 5) in neuroendocrine tumors using real-Time Rt-PCR method and immunohistochemistry. Acta Histochemica and Cytochemica 45 167-176. (https://doi.org/10.1267/ahc.12006)

Modlin IM, Oberg K, Chung DC, Jensen RT, de Herder WW, Thakker RV, Caplin M, Delle Fave G, Kaltsas GA, Krenning EP, et al. 2008 Gastroenteropancreatic neuroendocrine tumours. Lancet Oncology 9 61-72. (https://doi.org/10.1016/S1470-2045(07)70410-2)

Modlin IM, Gustafsson BI, Moss SF, Pavel M, Tsolakis AV \& Kidd M $2010 a$ Chromogranin A - biological function and clinical utility in neuro endocrine tumor disease. Annals of Surgical Oncology 17 2427-2443. (https://doi.org/10.1245/s10434-010-1006-3)

Modlin IM, Gustafsson BI, Pavel M, Svejda B, Lawrence B \& Kidd M $2010 \mathrm{~b}$ A nomogram to assess small-intestinal neuroendocrine tumor ('carcinoid') survival. Neuroendocrinology 92 143-157. (https://doi. org/10.1159/000319784)

Modlin IM, Drozdov I \& Kidd M 2013 The identification of gut neuroendocrine tumor disease by multiple synchronous transcript analysis in blood. PLoS One 8 e63364. (https://doi.org/10.1371/ journal.pone.0063364)

Modlin IM, Drozdov I, Bodei L \& Kidd M 2014a Blood transcript analysis and metastatic recurrent small bowel carcinoid management. BMC Cancer 14 564. (https://doi.org/10.1186/14712407-14-564)

Modlin IM, Oberg K, Taylor A, Drozdov I, Bodei L \& Kidd M $2014 b$ Neuroendocrine tumor biomarkers: current status and perspectives. Neuroendocrinology 100 265-277. (https://doi.org/10.1159/000368363) https://erc.bioscientifica.com

https://doi.org/10.1530/ERC-18-0354 (c) 2019 Society for Endocrinology Published by Bioscientifica Ltd. Printed in Great Britain 
Modlin IM, Kidd M, Bodei L, Drozdov I \& Aslanian H 2015 The clinical utility of a novel blood-based multi-transcriptome assay for the diagnosis of neuroendocrine tumors of the gastrointestinal tract. American Journal of Gastroenterology 110 1223-1232. (https://doi. org/10.1038/ajg.2015.160)

Modlin IM, Bodei L \& Kidd M 2016 Neuroendocrine tumor biomarkers: from monoanalytes to transcripts and algorithms. Best Practice and Research in Clinical Endocrinology and Metabolism 30 59-77.

Namwongprom S, Wong FC, Tateishi U, Kim EE \& Boonyaprapa S 2008 Correlation of chromogranin A levels and somatostatin receptor scintigraphy findings in the evaluation of metastases in carcinoid tumors. Annals of Nuclear Medicine 22 237-243. (https://doi. org/10.1007/s12149-007-0123-y)

Nathke I 2006 Cytoskeleton out of the cupboard: colon cancer and cytoskeletal changes induced by loss of APC. Nature Reviews Cancer $\mathbf{6}$ 967-974.

Nehar D, Lombard-Bohas C, Olivieri S, Claustrat B, Chayvialle JA, Penes MC, Sassolas G \& Borson-Chazot F 2004 Interest of chromogranin A for diagnosis and follow-up of endocrine tumours. Clinical Endocrinology 60 644-652. (https://doi. org/10.1111/j.1365-2265.2004.02030.x)

Niederle B, Pape U-F, Costa F, Gross D, Kelestimur F, Knigge U, Oberg K, Pavel M, Perren A, Toumpanakis C, et al. 2016 ENETS consensus guidelines update for neuroendocrine neoplasms of the jejunum and ileum. Neuroendocrinology 103 125-138. (https://doi. org/10.1159/000443170)

Nikou GC, Marinou K, Thomakos P, Papageorgiou D, Sanzanidis V, Nikolaou P, Kosmidis C, Moulakakis A \& Mallas E 2008 Chromogranin A levels in diagnosis, treatment and follow-up of 42 patients with non-functioning pancreatic endocrine tumours. Pancreatology 8 510-519.

Niu G \& Chen X 2010 Vascular endothelial growth factor as an antiangiogenic target for cancer therapy. Current Drug Targets $\mathbf{1 1}$ 1000-1017.

Nobels FR, Kwekkeboom DJ, Coopmans W, Schoenmakers CH, Lindemans J, De Herder WW, Krenning EP, Bouillon R \& Lamberts SW 1997 Chromogranin A as serum marker for neuroendocrine neoplasia: comparison with neuron-specific enolase and the alpha-subunit of glycoprotein hormones. Journal of Clinical Endocrinology and Metabolism 82 2622-2628. (https://doi. org/10.1210/jcem.82.8.4145)

Nolan DJ, Ciarrocchi A, Mellick AS, Jaggi JS, Bambino K, Gupta S, Heikamp E, McDevitt MR, Scheinberg DA, Benezra R, et al. 2007 Bone marrow-derived endothelial progenitor cells are a major determinant of nascent tumor neovascularization. Genes and Development 21 1546-1558. (https://doi.org/10.1101/gad.436307)

Nolting S, Kuttner A, Lauseker M, Vogeser M, Haug A, Herrmann KA, Hoffmann JN, Spitzweg C, Goke B \& Auernhammer CJ 2012 Chromogranin A as serum marker for gastroenteropancreatic neuroendocrine tumors: a single center experience and literature review. Cancers 4 141-155.

Oberg K, Knigge U, Kwekkeboom D \& Perren A \& Group EGW 2012 Neuroendocrine gastro-entero-pancreatic tumors ESMO Clinical Practice Guidelines for diagnosis, treatment and follow-up. Annals of Oncology 23 (Supplement 7) vii124-vii130.

Oberg K, Modlin IM, De Herder W, Pavel M, Klimstra D, Frilling A, Metz DC, Heaney A, Kwekkeboom D, Strosberg J, et al. 2015 Consensus on biomarkers for neuroendocrine tumour disease. Lancet Oncology 16 e435-e446.

Oberg K, Krenning E, Sundin A, Bodei L, Kidd M, Tesselaar M, Ambrosini V, Baum RP, Kulke M, Pavel M, et al. 2016 A Delphic consensus assessment: imaging and biomarkers in gastroenteropancreatic neuroendocrine tumor disease management. Endocrine Connections 5 174-187. (https://doi.org/10.1530/EC-16-0043)

Oberg K, Couvelard A, Delle Fave G, Gross D, Grossman A, Jensen RT, Pape UF, Perren A, Rindi G, Ruszniewski P, et al. 2017 Enets consensus guidelines for standard of care in neuroendocrine tumours: biochemical markers. Neuroendocrinology 105 201-211. (https://doi.org/10.1159/000472254)

Obexer P \& Ausserlechner MJ 2014 X-linked inhibitor of apoptosis protein - a critical death resistance regulator and therapeutic target for personalized cancer therapy. Frontiers in Oncology 4 197. (https:// doi.org/10.3389/fonc.2014.00197)

Ohaegbulam KC, Assal A, Lazar-Molnar E, Yao Y \& Zang X 2015 Human cancer immunotherapy with antibodies to the PD-1 and PD-L1 pathway. Trends in Molecular Medicine 21 24-33.

O'Toole D, Grossman A, Gross D, Delle Fave G, Barkmanova J, O'Connor J, Pape UF, Plockinger U \& Mallorca Consensus Conference \& European Neuroendocrine Tumor S 2009 ENETS consensus guidelines for the standards of care in neuroendocrine tumors biochemical markers. Neuroendocrinology 90 194-202.

Ozbudak IH, Shilo K, Tavora F, Rassaei N, Chu WS, Fukuoka J, Jen J, Travis WD \& Franks TJ 2009 Glucose transporter-1 in pulmonary neuroendocrine carcinomas: expression and survival analysis. Modern Pathology 22 633-638. (https://doi.org/10.1038/modpathol.2009.6)

Paez JG, Janne PA, Lee JC, Tracy S, Greulich H, Gabriel S, Herman P, Kaye FJ, Lindeman N, Boggon TJ, et al. 2004 EGFR mutations in lung cancer: correlation with clinical response to gefitinib therapy. Science 304 1497-1500. (https://doi.org/10.1126/science.1099314)

Panarelli N, Tyryshkin K, Wong JJM, Majewski A, Yang X, Scognamiglio T, Kim MK, Bogardus K, Tuschl T, Chen YT, et al. 2019 Evaluating gastroenteropancreatic neuroendocrine tumors through microRNA sequencing. Endocrine-Related Cancer 26 47-57. (https:// doi.org/10.1530/ERC-18-0244)

Panzuto F, Severi C, Cannizzaro R, Falconi M, Angeletti S, Pasquali A, Corleto VD, Annibale B, Buonadonna A, Pederzoli P, et al. 2004 Utility of combined use of plasma levels of chromogranin A and pancreatic polypeptide in the diagnosis of gastrointestinal and pancreatic endocrine tumors. Journal of Endocrinological Investigation 27 6-11. (https://doi.org/10.1007/BF03350903)

Pape UF, Bohmig M, Berndt U, Tiling N, Wiedenmann B \& Plockinger U 2004 Survival and clinical outcome of patients with neuroendocrine tumors of the gastroenteropancreatic tract in a German referral center. Annals of the New York Academy of Sciences 1014 222-233.

Park C, Ha SY, Kim ST, Kim HC, Heo JS, Park YS, Lauwers G, Lee J \& Kim KM 2016 Identification of the BRAF V600E mutation in gastroenteropancreatic neuroendocrine tumors. Oncotarget 7 4024-4035. (https://doi.org/10.18632/oncotarget.6602)

Parr C, Watkins G, Boulton M, Cai J \& Jiang WG 2005 Placenta growth factor is over-expressed and has prognostic value in human breast cancer. European Journal of Cancer 41 2819-2827.

Pavel ME, Hassler G, Baum U, Hahn EG, Lohmann T \& Schuppan D 2005 Circulating levels of angiogenic cytokines can predict tumour progression and prognosis in neuroendocrine carcinomas. Clinical Endocrinology 62 434-443.

Pavel ME, Hainsworth JD, Baudin E, Peeters M, Horsch D, Winkler RE, Klimovsky J, Lebwohl D, Jehl V, Wolin EM, et al. 2011 Everolimus plus octreotide long-acting repeatable for the treatment of advanced neuroendocrine tumours associated with carcinoid syndrome (RADIANT-2): a randomised, placebo-controlled, phase 3 study. Lancet 378 2005-2012. (https://doi.org/10.1016/S01406736(11)61742-X)

Pavel ME, Baudin E, Oberg KE, Hainsworth JD, Voi M, Rouyrre N, Peeters M, Gross DJ \& Yao JC 2017 Efficacy of everolimus plus octreotide LAR in patients with advanced neuroendocrine tumor and carcinoid syndrome: final overall survival from the randomized, placebo-controlled phase 3 RADIANT-2 study. Annals of Oncology 28 $1569-1575$.

Powles T, Eder JP, Fine GD, Braiteh FS, Loriot Y, Cruz C, Bellmunt J, Burris HA, Petrylak DP, Teng SL, et al. 2014 MPDL3280A (anti-PD-L1) treatment leads to clinical activity in metastatic bladder cancer. Nature $\mathbf{5 1 5} 558-562$. (c) 2019 Society for Endocrinology Published by Bioscientifica Ltd. Printed in Great Britain 
Raj N, Klimstra DS, Horvat N, Zhang L, Chou JF, Capanu M, Basturk O, Do RKG, Allen PJ \& Reidy-Lagunes D 2017 O6-methylguanine DNA methyltransferase status does not predict response or resistance to alkylating agents in well-differentiated pancreatic neuroendocrine tumors. Pancreas 46 758-763. (https://doi.org/10.1097/ MPA.0000000000000842)

Ramage JK, Ahmed A, Ardill J, Bax N, Breen DJ, Caplin ME, Corrie P, Davar J, Davies AH, Lewington V, et al. 2012 Guidelines for the management of gastroenteropancreatic neuroendocrine (including carcinoid) tumours (NETs). Gut 61 6-32. (https://doi.org/10.1136/ gutjnl-2011-300831)

Reddy KB 2015 MicroRNA (miRNA) in cancer. Cancer Cell International 15 38. (https://doi.org/10.1186/s12935-015-0185-1)

Resel Folkersma L, San Jose Manso L, Galante Romo I, Moreno Sierra J \& Olivier Gomez C 2012 Prognostic significance of circulating tumor cell count in patients with metastatic hormone-sensitive prostate cancer. Urology 80 1328-1332.

Reubi JC, Waser B, Cescato R, Gloor B, Stettler C \& Christ E 2010 Internalized somatostatin receptor subtype 2 in neuroendocrine tumors of octreotide-treated patients. Journal of Clinical Endocrinology and Metabolism 95 2343-2350. (https://doi.org/10.1210/jc.20092487)

Rickman OB, Vohra PK, Sanyal B, Vrana JA, Aubry MC, Wigle DA \& Thomas CF, Jr 2009 Analysis of ErbB receptors in pulmonary carcinoid tumors. Clinical Cancer Research 15 3315-3324. (https:// doi.org/10.1158/1078-0432.CCR-08-2549)

Righi L, Volante M, Tavaglione V, Bille A, Daniele L, Angusti T, Inzani F, Pelosi G, Rindi G \& Papotti M 2010 Somatostatin receptor tissue distribution in lung neuroendocrine tumours: a clinicopathologic and immunohistochemical study of 218 'clinically aggressive' cases. Annals of Oncology 21 548-555. (https://doi.org/10.1093/annonc/ mdp334)

Rizzo FM \& Meyer T 2018 Liquid biopsies for neuroendocrine tumors: circulating tumor cells, DNA, and microRNAs. Endocrinology and Metabolism Clinics of North America 47 471-483.

Roberts JA, Gonzalez RS, Das S, Berlin J \& Shi C 2017 Expression of PD-1 and PD-L1 in poorly differentiated neuroendocrine carcinomas of the digestive system: a potential target for anti-PD-1/PD-L1 therapy. Human Pathology 70 49-54. (https://doi.org/10.1016/j. humpath.2017.10.003)

Roldo C, Missiaglia E, Hagan JP, Falconi M, Capelli P, Bersani S, Calin GA, Volinia S, Liu CG, Scarpa A, et al. 2006 MicroRNA expression abnormalities in pancreatic endocrine and acinar tumors are associated with distinctive pathologic features and clinical behavior. Journal of Clinical Oncology 24 4677-4684. (https://doi. org/10.1200/JCO.2005.05.5194)

Rothe F, Laes JF, Lambrechts D, Smeets D, Vincent D, Maetens M, Fumagalli D, Michiels S, Drisis S, Moerman C, et al. 2014 Plasma circulating tumor DNA as an alternative to metastatic biopsies for mutational analysis in breast cancer. Annals of Oncology $\mathbf{2 5}$ 1959-1965. (https://doi.org/10.1093/annonc/mdu288)

Ruebel K, Leontovich AA, Stilling GA, Zhang S, Righi A, Jin L \& Lloyd RV 2010 MicroRNA expression in ileal carcinoid tumors: downregulation of microRNA-133a with tumor progression. Modern Pathology 23 367-375.

Rusch VW, Klimstra DS \& Venkatraman ES 1996 Molecular markers help characterize neuroendocrine lung tumors. Annals of Thoracic Surgery 62 798-809; discussion 809-710.

Sabatier R, Finetti P, Mamessier E, Adelaide J, Chaffanet M, Ali HR, Viens P, Caldas C, Birnbaum D \& Bertucci F 2015 Prognostic and predictive value of PDL1 expression in breast cancer. Oncotarget 6 5449-5464. (https://doi.org/10.18632/oncotarget.3216)

Sampedro-Nunez M, Luque RM, Ramos-Levi AM, Gahete MD, SerranoSomavilla A, Villa-Osaba A, Adrados M, Ibanez-Costa A, MartinPerez E, Culler MD, et al. 2016 Presence of sst5TMD4, a truncated splice variant of the somatostatin receptor subtype 5 , is associated to features of increased aggressiveness in pancreatic neuroendocrine tumors. Oncotarget 7 6593-6608.

Scarpa A, Chang DK, Nones K, Corbo V, Patch AM, Bailey P, Lawlor RT, Johns AL, Miller DK, Mafficini A, et al. 2017 Whole-genome landscape of pancreatic neuroendocrine tumours. Nature 543 65-71. (https://doi.org/10.1038/nature21063)

Schimmack S, Lawrence B, Svejda B, Alaimo D, Schmitz-Winnenthal H, Fischer L, Buchler MW, Kidd M \& Modlin I 2012 The clinical implications and biologic relevance of neurofilament expression in gastroenteropancreatic neuroendocrine neoplasms. Cancer 118 2763-2775. (https://doi.org/10.1002/cncr.26592)

Schmitt AM, Pavel M, Rudolph T, Dawson H, Blank A, Komminoth P, Vassella E \& Perren A 2014 Prognostic and predictive roles of MGMT protein expression and promoter methylation in sporadic pancreatic neuroendocrine neoplasms. Neuroendocrinology 100 35-44. (https:// doi.org/10.1159/000365514)

Schuller M, Jenne D \& Voltz R 2005 The human PNMA family: novel neuronal proteins implicated in paraneoplastic neurological disease. Journal of Neuroimmunology 169 172-176. (https://doi.org/10.1016/j. jneuroim.2005.08.019)

Schultheis AM, Scheel AH, Ozretic L, George J, Thomas RK, Hagemann T, Zander T, Wolf J \& Buettner R 2015 PD-L1 expression in small cell neuroendocrine carcinomas. European Journal of Cancer 51 421-426. (https://doi.org/10.1016/j.ejca.2014.12.006)

Schurmann G, Raeth U, Wiedenmann B, Buhr H \& Herfarth C 1992 Serum chromogranin A in the diagnosis and follow-up of neuroendocrine tumors of the gastroenteropancreatic tract. World Journal of Surgery 16 697-701; discussion 701-692.

Schwartz TW 1983 Pancreatic polypeptide: a hormone under vagal control. Gastroenterology 85 1411-1425.

Schwartzentruber J, Korshunov A, Liu XY, Jones DT, Pfaff E, Jacob K, Sturm D, Fontebasso AM, Quang DA, Tonjes M, et al. 2012 Driver mutations in histone H3.3 and chromatin remodelling genes in paediatric glioblastoma. Nature 482 226-231. (https://doi. org/10.1038/nature10833]

Seregni E, Ferrari L, Bajetta E, Martinetti A \& Bombardieri E 2001 Clinical significance of blood chromogranin A measurement in neuroendocrine tumours. Annals of Oncology 12 (Supplement 2) S69S72.

Shah T, Hochhauser D, Frow R, Quaglia A, Dhillon AP \& Caplin ME 2006 Epidermal growth factor receptor expression and activation in neuroendocrine tumours. Journal of Neuroendocrinology 18 355-360. (https://doi.org/10.1111/j.1365-2826.2006.01425.x)

Sikora K, Bedin C, Vicentini C, Malpeli G, D'Angelo E, Sperandio N, Lawlor RT, Bassi C, Tortora G, Nitti D, et al. 2015 Evaluation of cellfree DNA as a biomarker for pancreatic malignancies. International Journal of Biological Markers 30 e136-e141. (https://doi.org/10.5301/ jbm.5000088)

Srivastava A, Alexander J, Lomakin I \& Dayal Y 2001 Immunohistochemical expression of transforming growth factor alpha and epidermal growth factor receptor in pancreatic endocrine tumors. Human Pathology 32 1184-1189. (https://doi.org/10.1053/ hupa.2001.28959)

Stevenson M, Lines KE \& Thakker RV 2018 Molecular genetic studies of pancreatic neuroendocrine tumors: new therapeutic approaches. Endocrinology and Metabolism Clinics of North America 47 525-548. (https://doi.org/10.1016/j.ecl.2018.04.007)

Stivanello M, Berruti A, Torta M, Termine A, Tampellini M, Gorzegno G, Angeli A \& Dogliotti L 2001 Circulating chromogranin A in the assessment of patients with neuroendocrine tumours. A single institution experience. Annals of Oncology 12 (Supplement 2) S73S77.

Strosberg J, El-Haddad G, Wolin E, Hendifar A, Yao J, Chasen B, Mittra E, Kunz PL, Kulke MH, Jacene H, et al. 2017 Phase 3 trial of (177)Lu-Dotatate for midgut neuroendocrine tumors. New England Journal of Medicine 376 125-135. (c) 2019 Society for Endocrinology Published by Bioscientifica Ltd. Printed in Great Britain 
Tecimer T, Dlott J, Chuntharapai A, Martin AW \& Peiper SC 2000 Expression of the chemokine receptor CXCR2 in normal and neoplastic neuroendocrine cells. Archives of Pathology and Laboratory Medicine 124 520-525. (https://doi.org/10.1043/00039985(2000)124<0520:EOTCRC>2.0.CO;2)

Terris B, Scoazec JY, Rubbia L, Bregeaud L, Pepper MS, Ruszniewski P, Belghiti J, Flejou J \& Degott C 1998 Expression of vascular endothelial growth factor in digestive neuroendocrine tumours. Histopathology 32 133-138.

Thorns C, Schurmann C, Gebauer N, Wallaschofski H, Kumpers C, Bernard V, Feller AC, Keck T, Habermann JK, Begum N, et al. 2014 Global microRNA profiling of pancreatic neuroendocrine neoplasias. Anticancer Research 34 2249-2254.

Tomassetti P, Migliori M, Simoni P, Casadei R, De Iasio R, Corinaldesi R \& Gullo L 2001 Diagnostic value of plasma chromogranin A in neuroendocrine tumours. European Journal of Gastroenterology and Hepatology 13 55-58.

Tsuruoka K, Horinouchi H, Goto Y, Kanda S, Fujiwara Y, Nokihara H, Yamamoto N, Asakura K, Nakagawa K, Sakurai H, et al. 2017 PD-L1 expression in neuroendocrine tumors of the lung. Lung Cancer 108 115-120.

Turner GB, Johnston BT, McCance DR, McGinty A, Watson RG, Patterson CC \& Ardill JE 2006 Circulating markers of prognosis and response to treatment in patients with midgut carcinoid tumours. Gut 55 1586-1591. (https://doi.org/10.1136/gut.2006.092320)

van Adrichem RC, Kamp K, van Deurzen CH, Biermann K, Feelders RA, Franssen GJ, Kwekkeboom DJ, Hofland LJ \& de Herder WW $2016 a$ Is there an additional value of using somatostatin receptor subtype $2 \mathrm{a}$ immunohistochemistry compared to somatostatin receptor scintigraphy uptake in predicting gastroenteropancreatic neuroendocrine tumor response? Neuroendocrinology 103 560-566. (https://doi.org/10.1159/000441604)

van Adrichem RC, Kamp K, Vandamme T, Peeters M, Feelders RA \& de Herder WW $2016 b$ Serum neuron-specific enolase level is an independent predictor of overall survival in patients with gastroenteropancreatic neuroendocrine tumors. Annals of Oncology 27 746-747. (https://doi.org/10.1093/annonc/mdv626)

van der Zwan WA, Bodei L, Mueller-Brand J, de Herder WW, Kvols LK \& Kwekkeboom DJ 2015 GEPNETs update: radionuclide therapy in neuroendocrine tumors. European Journal of Endocrinology 172 R1-R8. (https://doi.org/10.1530/EJE-14-0488)

van't Veer LJ, Dai H, van de Vijver MJ, He YD, Hart AA, Mao M, Peterse HL, van der Kooy K, Marton MJ, Witteveen AT, et al. 2002 Gene expression profiling predicts clinical outcome of breast cancer. Nature 415 530-536. (https://doi.org/10.1038/415530a)

VandenBussche CJ, Allison DB, Graham MK, Charu V, Lennon AM, Wolfgang CL, Hruban RH \& Heaphy CM 2017 Alternative lengthening of telomeres and ATRX/DAXX loss can be reliably detected in FNAs of pancreatic neuroendocrine tumors. Cancer Cytopathology 125 544-551. (https://doi.org/10.1002/cncy.21857)

Veenendaal LM, Borel Rinkes IH, Lips CJ \& van Hillegersberg R 2006 Liver metastases of neuroendocrine tumours; early reduction of tumour load to improve life expectancy. World Journal of Surgical Oncology 4 35. (https://doi.org/10.1186/1477-7819-4-35)

Vestergaard EM, Nexo E, Torring N, Borre M, Orntoft TF \& Sorensen KD 2010 Promoter hypomethylation and upregulation of trefoil factors in prostate cancer. International Journal of Cancer 127 1857-1865.

Vicentini C, Fassan M, D’Angelo E, Corbo V, Silvestris N, Nuovo GJ \& Scarpa A 2014 Clinical application of microRNA testing in neuroendocrine tumors of the gastrointestinal tract. Molecules 19 2458-2468. (https://doi.org/10.3390/molecules19022458)

Walter T, Chardon L, Chopin-laly X, Raverot V, Caffin AG, Chayvialle JA, Scoazec JY \& Lombard-Bohas C 2012 Is the combination of chromogranin A and pancreatic polypeptide serum determinations of interest in the diagnosis and follow-up of gastro-entero-pancreatic neuroendocrine tumours? European Journal of Cancer 48 1766-1773. (https://doi.org/10.1016/j.ejca.2011.11.005)

Walter T, van Brakel B, Vercherat C, Hervieu V, Forestier J, Chayvialle JA, Molin Y, Lombard-Bohas C, Joly MO \& Scoazec JY 2015 O6-Methylguanine-DNA methyltransferase status in neuroendocrine tumours: prognostic relevance and association with response to alkylating agents. British Journal of Cancer 112 523-531. (https://doi. org/10.1038/bjc.2014.660)

Wang YH, Yang QC, Lin Y, Xue L, Chen MH \& Chen J 2014 Chromogranin A as a marker for diagnosis, treatment, and survival in patients with gastroenteropancreatic neuroendocrine neoplasm. Medicine 93 e247. (https://doi.org/10.1097/MD.0000000000000247)

Wei SC, Liang JT, Tsao PN, Hsieh FJ, Yu SC \& Wong JM 2009 Preoperative serum placenta growth factor level is a prognostic biomarker in colorectal cancer. Diseases of the Colon and Rectum 52 1630-1636. (https://doi.org/10.1007/DCR.0b013e3181afbdaf)

Wong KK, Waterfield RT, Marzola MC, Scarsbrook AF, Chowdhury FU, Gross MD \& Rubello D 2012 Contemporary nuclear medicine imaging of neuroendocrine tumours. Clinical Radiology 67 1035-1050. (https://doi.org/10.1016/j.crad.2012.03.019)

Wu X, Zhi X, Ji M, Wang Q, Li Y, Xie J \& Zhao S 2015 Midkine as a potential diagnostic marker in epithelial ovarian cancer for cisplatin/ paclitaxel combination clinical therapy. American Journal of Cancer Research 5 629-638.

Xavier S, Rosa B \& Cotter J 2016 Small bowel neuroendocrine tumors: from pathophysiology to clinical approach. World Journal of Gastrointestinal Pathophysiology 7 117-124. (https://doi.org/10.4291/ wjgp.v7.i1.117)

Yao JC, Hassan M, Phan A, Dagohoy C, Leary C, Mares JE, Abdalla EK, Fleming JB, Vauthey JN, Rashid A, et al. 2008 One hundred years after 'carcinoid': epidemiology of and prognostic factors for neuroendocrine tumors in 35,825 cases in the United States. Journal of Clinical Oncology 26 3063-3072. (https://doi.org/10.1200/ JCO.2007.15.4377)

Yao JC, Lombard-Bohas C, Baudin E, Kvols LK, Rougier P, Ruszniewski P, Hoosen S, St Peter J, Haas T, Lebwohl D, et al. 2010 Daily oral everolimus activity in patients with metastatic pancreatic neuroendocrine tumors after failure of cytotoxic chemotherapy: a phase II trial. Journal of Clinical Oncology 28 69-76. (https://doi. org/10.1200/JCO.2009.24.2669)

Yao JC, Pavel M, Phan AT, Kulke MH, Hoosen S, St Peter J, Cherfi A \& Öberg KE 2011 Chromogranin A and neuron-specific enolase as prognostic markers in patients with advanced pNET treated with everolimus. Journal of Clinical Endocrinology and Metabolism 96 3741-3749. (https://doi.org/10.1210/jc.2011-0666)

Yao JC, Shah M PanneerselvamA, Stergiopoulos S, Chen D, Ito T \& Pavel M 2012 The VEGF pathway in patients with pancreatic neuroendocrine tumors: efficacy of everolimus by baseline marker level, and prognostic and predictive effect analysis from radiant-3. ESMO Congress 2012 abstract 11540.

Yap TA, Yan L, Patnaik A, Fearen I, Olmos D, Papadopoulos K, Baird RD, Delgado L, Taylor A, Lupinacci L, et al. 2011 First-in-man clinical trial of the oral pan-AKT inhibitor MK-2206 in patients with advanced solid tumors. Journal of Clinical Oncology 29 4688-4695.

Zandee WT, Kamp K, van Adrichem RC, Feelders RA \& de Herder WW 2016 Limited value for urinary 5-HIAA excretion as prognostic marker in gastrointestinal neuroendocrine tumours. European Journal of Endocrinology 175 361-366. (https://doi.org/10.1530/EJE-16-0392)

Zatelli MC, Torta M, Leon A, Ambrosio MR, Gion M, Tomassetti P, De Braud F, Delle Fave G, Dogliotti L, degli Uberti EC, et al. 2007 Chromogranin A as a marker of neuroendocrine neoplasia: an Italian multicenter study. Endocrine-Related Cancer 14 473-482. (https://doi. org/10.1677/ERC-07-0001)

Zatelli MC, Grossrubatscher EM, Guadagno E, Sciammarella C, Faggiano A \& Colao A 2017 Circulating tumor cells and miRNAs as https://erc bioscientifica com

https://doi.org/10.1530/ERC-18-0354 (c) 2019 Society for Endocrinology Published by Bioscientifica Ltd. Printed in Great Britain 
prognostic markers in neuroendocrine neoplasms. Endocrine-Related Cancer 24 R223-R237. (https://doi.org/10.1530/ERC-17-0091)

Zhang J, Jia Z, Li Q, Wang L, Rashid A, Zhu Z, Evans DB, Vauthey JN, Xie K \& Yao JC 2007 Elevated expression of vascular endothelial growth factor correlates with increased angiogenesis and decreased progression-free survival among patients with low-grade neuroendocrine tumors. Cancer 109 1478-1486. (https://doi. org/10.1002/cncr.22554)

Zimmermann N, Knief J, Kacprowski T, Lazar-Karsten P, Keck T, Billmann F, Schmid S, Luley K, Lehnert H, Brabant G, et al. 2018 MicroRNA analysis of gastroenteropancreatic neuroendocrine tumors and metastases. Oncotarget 9 28379-28390. (https://doi. org/10.18632/oncotarget.25357)

Zuetenhorst JM \& Taal BG 2005 Metastatic carcinoid tumors: a clinical review. Oncologist 10 123-131. (https://doi.org/10.1634/ theoncologist.10-2-123)

Zurita AJ, Khajavi M, Wu HK, Tye L, Huang X, Kulke MH, Lenz HJ, Meropol NJ, Carley W, DePrimo SE, et al. 2015 Circulating cytokines and monocyte subpopulations as biomarkers of outcome and biological activity in sunitinib-treated patients with advanced neuroendocrine tumours. British Journal of Cancer 112 1199-1205. (https://doi.org/10.1038/bjc.2015.73)

Received in final form 12 December 2018

Accepted 3 January 2019

Accepted Preprint published online 7 January 2019 (c) 2019 Society for Endocrinology Published by Bioscientifica Ltd. Printed in Great Britain 